\title{
Short-Term Reversals: The Effects of Past Returns and Institutional Exits
}

\author{
Si Cheng, Allaudeen Hameed, Avanidhar Subrahmanyam, and \\ Sheridan Titman*
}

\begin{abstract}
Price declines over the previous quarter lead to stronger reversals across the subsequent 2 months. We explain this finding based on the dual notions that liquidity provision can influence reversals and that agents who act as de facto liquidity providers may be less active in past losers. Supporting these observations, we find that active institutions participate less in losing stocks and that the magnitude of monthly return reversals fluctuates with changes in the number of active institutional investors. Thus, we argue that fluctuations in liquidity provision with past return performance account for the link between return reversals and past returns.
\end{abstract}

\section{Introduction}

Since the discovery of monthly reversals by Jegadeesh (1990), considerable effort has been spent to understand this finding. We show that reversals are stronger for stocks that recently experienced a decline in market value. Specifically, reversals across months $t$ and $t+1$ are much stronger for the extreme quintile of losing stocks across months $t-3$ and $t-1$. The average monthly riskadjusted reversal profits for these loser quintile stocks range from $0.81 \%$ to $1.68 \%$ across all size groups but are not reliably different from 0 among stocks that are not extreme losers in the previous quarter. Moreover, in the post-2000 period,

\footnotetext{
*Cheng, sicheng@cuhk.edu.hk, Chinese University of Hong Kong; Hameed, allaudeen@nus .edu.sg, National University of Singapore; Subrahmanyam (corresponding author), subra@anderson .ucla.edu, Anderson School of Management, University of California at Los Angeles; and Titman, sheridan.titman@mccombs.utexas.edu, McCombs School of Business, University of Texas at Austin. We thank an anonymous referee, Aydogan Alti, Hendrik Bessembinder (the editor), Tarun Chordia, Elroy Dimson, John Griffin, Raghu Rau, Pedro Saffi, Tao Shu, Elvira Sojli, Avi Wohl, and seminar participants at the Asian Bureau of Finance and Economic Research (ABFER) and Asian Finance Association conferences, California State University, Fullerton, Erasmus University, the Hebrew University Conference to Honor Dan Galai and Itzhak Venezia, Hong Kong University of Science and Technology, National University of Singapore, Rutgers University, Stevens Institute of Technology, the University of Cambridge, the University of Missouri-Columbia, the University of Queensland, the University of St. Gallen, and the University of Texas at Austin for helpful comments. Hameed gratefully acknowledges financial support from NUS Academic Research Grants.
} 
where unconditional contrarian profits are not different from 0 on average, we still find evidence of risk-adjusted profits among stocks that decline in value in the previous quarter. For example, among the stocks in the loser quintile, the riskadjusted reversal profit in the post-2000 period ranges from $0.49 \%$ to $1.22 \%$ per month for the large, small, and microcap stocks.

Why might there be a link between past returns and contrarian profits? Three explanations come to mind. First, reversals might be associated with historical price performance because past returns influence the behavior of active institutions and thus affect liquidity provision. Second, fire sales induced by falling prices might cause an excessive price decline and a subsequent rebound. Third, losing stocks might experience greater reversals because they become more volatile, and liquidity provision and arbitrage are riskier when volatility increases. We find that the evidence supports the first rationale, which we explore in depth, with less support for the other two.

Our focus on liquidity provision is consistent with a number of existing papers that analyze reversals. ${ }^{1}$ We examine whether the larger reversal profits associated with losers in the previous quarter arise because of a decrease in the provision of liquidity for these stocks. Past stock price declines can induce exits by de facto liquidity providers (e.g., active institutions) for at least two reasons. First, institutional funds holding stocks that have performed poorly may face more outflows and be forced to sell some of the stocks they own. Second, window-dressing concerns (Ritter and Chopra (1989), Asness, Liew, and Stevens (1997)) might deter the inclusion of loser stocks in institutional portfolios. ${ }^{2}$

We use measures of active institutional investors proposed by Abarbanell, Bushee, and Raedy (2003) and Gaspar, Massa, and Matos (2005) as proxies for the mass of investors that actively follow and trade a particular stock. We find that extremely low (high) stock returns are associated with significant decreases (increases) in the numbers of these active institutional investors. We then test the implied relation between the magnitude of return reversals and changes in the number of active institutional investors. We find that the magnitude of return reversals is higher for those stocks that experience a decline in the number of active institutional holdings during the previous quarter. On the other hand, the reversal profits are small and not significantly different from 0 for the stocks that have an increase in active investors in the previous quarter. These findings together provide support for the notion that past returns influence liquidity provision and, in turn, contrarian profits via their impact on the entry/exit behavior of active institutions.

\footnotetext{
${ }^{1}$ Conrad, Kaul, and Nimalendran (1991), Jegadeesh and Titman (1995), and Kaniel, Saar, and Titman (2008) discuss how market microstructure phenomena such as inventory considerations can generate reversals. The inventory theory of price formation is elucidated by Stoll (1978), Ho and Stoll (1983), O’Hara and Oldfield (1986), Grossman and Miller (1988), and Spiegel and Subrahmanyam (1995).

${ }^{2}$ Negative stock returns can also ensue from institutional selling that is prompted by unfavorable information. With short-selling constraints, institutions have less incentive to actively collect information on stocks that they do not own, so any event that prompts institutional selling is likely to lead to decreased market-making capacity and increased contrarian profits. It should also be noted that institutions may sell losers to capture the momentum effect documented by Jegadeesh and Titman (1993). However, our results hold when the reversal profits are adjusted for momentum as well.
} 
We also consider the trading activities of liquidity-supplying (LS) institutions, as defined by Anand, Irvine, Puckett, and Venkataraman (2013). Specifically, we examine institutional trading data (from Abel Noser) and find that the relative proportion of trading volume by LS institutions decreases (increases) for stocks that have lost (gained) market value in the past quarter. This finding is consistent with LS institutions withdrawing from trading stocks that are losers in the previous period. We obtain similar findings when we use hedge funds to represent active investors that provide liquidity (Franzoni and Plazzi (2013)).

In further analysis, we examine the second explanation, which is that reversals are higher following low past returns because of the price pressure created by the "fire sales" of institutions following a prolonged period of low returns. For example, Coval and Stafford (2007) note that mutual fund fire sales generate persistent liquidity shocks, and Lou (2012) shows that mutual fund flows induce price pressure. The notion here is that after incurring losses over 3 months, institutions sell stocks in the subsequent month, causing a further decline in that month and a subsequent reversal. We show, however, that among 3-month losers, abnormal turnover is not higher for 1-month losers relative to 1-month winners. Further, the profits of reversals do not solely or primarily emanate from 1-month losers. These results are at odds with the fire-sales rationale for our results.

With regard to the third rationale (that falling stocks become more volatile and experience greater reversals), we note that Glosten, Jagannathan, and Runkle (1993) show that stocks with negative returns are more volatile, and Huang, Liu, Rhee, and Zhang (2010) argue that monthly return reversals are larger for more volatile stocks. However, we find significant return reversals for stocks that perform poorly in the past quarter, independent of the level of total return volatility or idiosyncratic volatility. Hence, our central finding cannot be adequately explained by the changes in the volatility of stock returns.

Our main findings supporting the liquidity-provision explanation are robust. First, our results survive when we exclude January months from the sample, indicating that the relation between reversals and institutional participation is not simply a consequence of tax-loss selling. Second, we use the Fama and MacBeth (1973) cross-sectional regression approach to control for other firm characteristics that may also proxy for illiquidity (Avramov, Chordia, and Goyal (2006), Huang et al. (2010)). As we show, the relation between changes in active institutional holdings, past 3-month returns, and monthly reversals continues to hold when we include these control variables.

We also find that the link between past returns and return reversals is a temporary phenomenon. Whereas returns in the previous quarter strongly predict contrarian profits, returns two quarters in the past have no reliable relation to the magnitude of the return reversal. This observation is consistent with the notion that in the long run, market-making capacity adjusts in response to active investor exits, restoring liquidity provision.

Although our focus is somewhat different, our research is part of a large and growing literature that motivates and/or examines short-term return reversals. Asparouhova, Bessembinder, and Kalcheva (2013) show that short-term reversals induced by inelastic liquidity supply can bias asset pricing tests by biasing observed returns upward. This indicates that liquidity provision is important 
for financial researchers beyond just being a microstructure issue. Hameed and Mian (2015) show that reversals are stronger when returns are industry adjusted, implicitly arguing that subtracting returns likely generated by fundamental (i.e., industry-wide) information rather than liquidity trades strengthens reversals. Other studies, such as those by Avramov et al. (2006), Da and Gao (2010), Hameed, Kang, and Viswanathan (2010), Nagel (2012), and Da, Liu, and Schaumburg (2014), refine the strategy by identifying stocks (and times) for which liquidity shocks are expected to be especially strong. ${ }^{3}$ Da and Gao (2010), who are primarily interested in explaining the abnormally high returns of distressed stocks, provide evidence that most of the abnormal returns are due to reversals of negative returns generated by price pressure when institutional investors sell these stocks. This evidence of institutional investors as liquidity demanders is in contrast to our focus, which is on the role that active institutions play as liquidity providers. Clearly, in reality, both roles are relevant.

Our paper is also related to more recent work that explores the link between institutional investor holdings and liquidity during the crisis period. For example, Aragon and Strahan (2012) show a significant decline in the liquidity of stocks held by Lehman-connected hedge funds following the Lehman bankruptcy in September 2008, and Anand et al. (2013) show that withdrawal of liquiditysupplying institutional investors during the 2007-2009 financial crisis amplified the illiquidity of the stocks, particularly the riskier securities. This evidence from the crisis supports the idea that the presence of active investors contributes to liquidity provision. However, our evidence suggests that, perhaps because of the introduction of quantitative traders, the disruptions to liquidity supply following institutional exits have decreased over time, particularly for large firms.

The paper is organized as follows: Section II describes our data and presents the main empirical results. Section III considers alternative explanations, followed by robustness tests in Section IV. Section V concludes the paper.

\section{Empirical Results}

\section{A. Data and Methodology}

Our sample consists of all common stocks trading at the New York Stock Exchange (NYSE), American Stock Exchange (AMEX), and National Association of Securities Dealers Automated Quotations (NASDAQ) with share code 10 or 11, obtained from the Center for Research in Security Prices (CRSP). The full sample period starts in Jan. 1980 and ends in Dec. 2011. Our sample begins in 1980 because some of the firm-specific variables we consider are only available from the 1980s. To minimize microstructure biases emanating from low-price stocks, we exclude "penny" stocks whose prices are below $\$ 5$ at the end of each month.

\footnotetext{
${ }^{3}$ We also find that the higher reversal profits among the past 3-month-loser stocks are not confined to periods of market declines or VIX increases, as documented by Hameed et al. (2010) and Nagel (2012).
} 
Our primary methodology involves sorting into quintiles based on stock returns in month $t$ and evaluating returns in month $t+1$. We implement the conventional contrarian strategy by taking long positions in the bottom quintile of stocks (loser portfolio) in the past month and shorting the stocks in the top quintile (winner portfolio). The zero-investment contrarian profit (Jegadeesh (1990)) is computed as the loser minus winner portfolio returns in month $t+1$.

We report the contrarian portfolio returns in month $t+1$ for all stocks as well as stocks sorted into size groups. The analysis across size groups is motivated by the findings of Fama and French (2008), who show that equal-weighted long-short portfolios may be dominated by stocks that are plentiful but tiny in size. Conversely, value-weighted portfolios are dominated by a few large firms, and hence the resulting portfolio returns are not representative of the profitability of the strategy. Thus, following Fama and French (2008), we group stocks into three categories based on the beginning-of-period market capitalization: microcaps (defined as stocks that are less than the 20th NYSE size percentile), small firms (stocks that are between the 20th and 50th NYSE size percentiles), and big firms (stocks that are above the 50th NYSE size percentile).

In addition to the equal-weighted raw contrarian portfolio returns for each category of stocks, we report alphas from a 4-factor model that consists of the 3 Fama and French (1993) factors (the market factor (excess return on the valueweighted CRSP market index over the 1-month T-bill rate; MKT), the size factor (small minus big firm return premium; SMB), the book-to-market factor (high book-to-market minus low book-to-market return premium; HML)) and the Pástor and Stambaugh (2003) liquidity factor. The alphas we report in the paper are robust to the addition of the momentum factor in a 5-factor model, suggesting an insignificant exposure to the factor (results are available from the authors). The standard errors in all the estimations are corrected for autocorrelation with 3 lags using the Newey and West (1987) method.

To examine the relation between return reversals and past returns, we sort stocks into portfolios based on their return performance in the past 1 quarter and past 1 month (see Figure 1 for the time line used). Specifically, in each month $t$, we sort stocks into quintiles based on returns over the previous 3 months, that is, months $t-3$ to $t-1$. The stocks in the lowest quintile are labeled as 3-month $(3 \mathrm{M})$ losers, and those in the top quintile are $3 \mathrm{M}$ winners. We also independently

FIGURE 1

Time Line Showing the Measurement Periods

Figure 1 presents the time line of the 3 measurement periods we consider in this paper. The first period consists of 3 months, months $t-3$ to $t-1$, and is used to measure the $3 \mathrm{M}$ return or the change in number of institutions over the same period. The second period (month $t$ ) is used as the formation month to sort stocks into $1 \mathrm{M}$ winners and losers. The contrarian strategy is implemented by taking long positions in the $1 \mathrm{M}$ losers and shorting $1 \mathrm{M}$ winners, and the zero-investment contrarian profit is computed as the loser minus winner portfolio returns in month $t+1$.

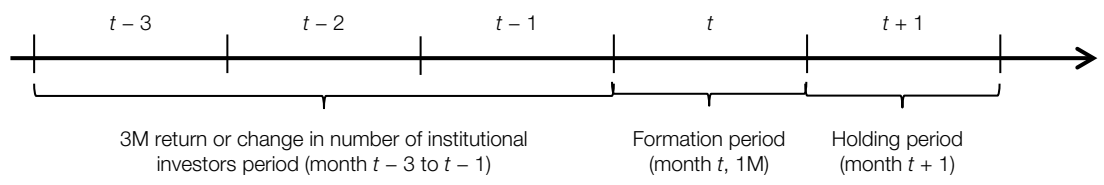


sort all stocks into 5 equal groups using their returns in month $t$ to produce 1month (1M) losers (stocks with the lowest month $t$ returns) and $1 \mathrm{M}$ winners (stocks with the highest month $t$ returns). The contrarian portfolio strategy, within each of the $3 \mathrm{M}$ return quintiles, consists of taking long positions in $1 \mathrm{M}$ losers and short positions in $1 \mathrm{M}$ winners.

Information about institutional investors is extracted from two sources. First, we use the Thomson Reuters Institutional Holdings (13F) database to obtain institutional holdings for the full sample of institutions required to report to the U.S. Securities and Exchange Commission (SEC) over the period 1980 to 2011 . $^{4}$ We break down the institutional investors into active and passive types following Abarbanell et al. (2003), where investment companies and independent investment advisors are generally considered to be active investors. We exclude other institutions, such as bank trusts, insurance companies, corporate/private pension funds, public pension funds, and university and foundation endowments, that have longer investment horizons and trade less actively. ${ }^{5}$ We compute the number of active institutional investors holding shares in a firm at the end of each quarter, labeled as ACTIVE, and denote a change in the number of active institutional investors over the quarter as $\triangle$ ACTIVE. $^{6}$ Details on the construction of all variables are provided in the Appendix.

Our premise is based on the notion that active investors, who may have proprietary information, act as de facto market makers. It is natural to ask whether active institutions, such as those defined by Abarbanell et al. (2003), actually are informed about the stocks they hold, thus giving them a motive for being present in the market for these stocks. In this regard, Ke and Petroni (2004) show that transient institutional investors are able to predict a break in a string of consecutive quarterly earnings increases. Yan and Zhang (2009) find that changes in the holdings of short-term institutional investors predict 1-quarter-ahead stock returns. Consistent with the notion that the active institutional investors, on average, can predict future stock price movements, we find a significant positive relation between $\triangle$ ACTIVE for stock $i$ in quarter $q$ and the return on stock $i$ in the subsequent quarter. As shown in Internet Appendix Table IA1 (available at www .jfqa.org), in regressions of quarterly returns on measures of holdings (in the style of Fama and MacBeth (1973)), we find that $\triangle$ ACTIVE in the past quarter (or a dummy variable indicating increases in ACTIVE) significantly predicts future stock returns. Conversely, similar increases in the holdings of other institutions defined by Abarbanell et al. (2003) as inactive investors (which we denote as Passive) are not related to subsequent stock returns. These findings control for the predictive effects of other firm characteristics, such as firm size, book-to-market

\footnotetext{
${ }^{4}$ The institutional ownership data come from the quarterly $13 \mathrm{~F}$ filings of money managers to the SEC. The database contains the positions of all the institutional investment managers with more than $\$ 100$ million under discretionary management. All holdings worth more than $\$ 200,000$ or 10,000 shares are reported in the database.

${ }^{5}$ We thank Brian Bushee for making the institutional investor classification data available at his Web site (http://acct.wharton.upenn.edu/faculty/bushee/IIclass.html).

${ }^{6} \mathrm{We}$ obtain similar results when institutional holdings are measured by the percentage of shares held rather than the number of institutional shareholders.
} 
ratio, past returns, illiquidity, turnover, and volatility. Thus, on average, changes in active investors' holdings predict returns, suggesting that at least some of them are informed.

Following the work by Gaspar et al. (2005) and Yan and Zhang (2009), we also consider an alternative definition of active institutional investors based on institutions' portfolio turnover. Intuitively, short-term investors buy and sell the stocks in their portfolios frequently. Each institutional investor's quarterly churn (or turnover) rate is measured based on the purchase and sale of stocks in the institution's portfolio. We classify those institutions with turnover rates above the median turnover ratio of all institutions in the past 4 quarters as short-term investors (SHORT_TERM), and the remaining institutions are labeled LONG_TERM. Using a similar definition, Yan and Zhang (2009) find that short-term institutional investors are better informed.

Our second data source is the institutional trading data provided by Abel Noser Solutions (Abel Noser) for the period Jan. 1999-Dec. 2011. Abel Noser is a well-known consulting firm that provides transaction cost analysis for its institutional clients. The data set contains intraday buy and sell trades by its institutional clients, and the institutional coverage has been found to be comparable to that in 13F filings (see Puckett and Yan (2011), Anand, Puckett, and Venkataraman (2012), (2013)). ${ }^{7}$

We follow Anand et al. (2013) in calculating the trading style for each institution in Abel Noser based on whether the institution's daily trade in a stock is in the same direction as the stock's contemporaneous daily return. If the institution belongs to the lowest (highest) tercile of all institutions with its trading volume in the same direction as the daily stock returns in the prior month, it is considered to be a liquidity-supplying or LS (liquidity-demanding or LD) institution. Detailed definitions of LS and LD institutions are provided in the Appendix. Anand et al. (2013) report that the LS (and LD) institutions are highly persistent and capture the variation in liquidity provision around the 2008 financial crisis.

\section{B. Prior Quarterly Returns and Monthly Return Reversals}

Table 1 contains the returns to the monthly contrarian investment portfolios. In Panel A, we report the returns to the contrarian portfolio strategy formed using all stocks in our sample. Over the 1980-2011 sample period, the (equalweighted) average contrarian return across all stocks is a significant $0.54 \%$ per month. We also obtain significant raw profits in each of the three groups of microcaps, small, and big firms. However, the profits weaken considerably after adjusting for risk exposures using the 4-factor model and become insignificant, except for microcaps.

Next, we examine the profits to the contrarian strategy when conditioned on past stock returns. The independent sorting of stocks into quintiles based on past $3 \mathrm{M}$ returns (over months $t-3$ to $t-1$ ) and past $1 \mathrm{M}$ (or month $t$ ) returns gives us 25 portfolios. We calculate their mean holding period returns in month $t+1$

\footnotetext{
${ }^{7}$ Other studies that have made extensive use of the Abel Noser database to investigate institutional investor behavior include those by Chemmanur, $\mathrm{He}$, and $\mathrm{Hu}$ (2009), Goldstein, Irvine, Kandel, and Weiner (2009), Goldstein, Irvine, and Puckett (2011), and Franzoni and Plazzi (2013).
} 
for each of the 5 quintiles based on $3 \mathrm{M}$ returns. The basic findings on reversal profits change dramatically when we condition on past stock returns, as shown in Table 1. Monthly contrarian profits increase drastically when we move from the $3 \mathrm{M}$ winner quintile to the $3 \mathrm{M}$ loser quintile. In Panel $\mathrm{A}$, the equalweighted contrarian portfolio of all stocks produces the highest reversal return

\section{TABLE 1}

\section{Returns to Contrarian Investment Strategies: Effect of Past 3-Month Returns}

In Table 1, stocks are sorted into the 3 size groups of microcaps, small stocks, and big stocks, using the NYSE 20th and 50th percentiles as breakpoints. Within each size group, stocks are further sorted into quintiles according to their month $t$ returns. The loser (winner) portfolio comprises the bottom (top) quintile of stocks based on the returns in month $t$. Panel A first reports, for each size group (micro, small, and big) and all firms, the equal-weighted return in month $t+1$ for the contrarian strategy of going long (short) with the loser (winner) stocks. The profits are reported for the full sample from 1980 to 2011. Within each size group, stocks are independently sorted into quintiles according to their lagged 3-month accumulated returns $(t-3$ to $t-1)$ and 1 -month returns $(t)$, generating $25(5 \times 5)$ portfolios. Panel $\mathrm{A}$ also reports the month $t+1$ return for the similar strategy for each subgroup of stocks according to the 3 -month returns. Risk-adjusted returns are based on a 4-factor model comprising the 3 Fama-French (1993) factors (market, size, and book-to-market) and the Pástor-Stambaugh (2003) liquidity factor. Panels B and C report similar statistics in 2 subperiods: 1980-1999 (Panel B) and 2000-2011 (Panel C). The row "LMW" reports the difference in profits between 3-month loser and winner portfolios, and $t$-statistics adjusted using the Newey-West (1987) method are reported in parentheses. * **, and *** indicate significance at the $10 \%, 5 \%$, and $1 \%$ levels, respectively.

Panel A. Returns to Contrarian Investment Strategies and Past 3-Month Returns (1980-2011)

\begin{tabular}{|c|c|c|c|c|c|c|c|c|}
\hline \multirow{3}{*}{$\begin{array}{c}\text { Rank of Past } \\
\text { 3-Month Returns } \\
\end{array}$} & \multicolumn{4}{|c|}{ Returns } & \multicolumn{4}{|c|}{ 4-Factor Adjusted Returns } \\
\hline & \multicolumn{3}{|c|}{ Firm Size } & \multirow[b]{2}{*}{ All } & \multicolumn{3}{|c|}{ Firm Size } & \multirow[b]{2}{*}{ All } \\
\hline & Micro & Small & Big & & Micro & Small & Big & \\
\hline All & $\begin{array}{l}0.626^{\star * *} \\
(3.32)\end{array}$ & $\begin{array}{l}0.556^{\star \star} \\
(2.40)\end{array}$ & $\begin{array}{l}0.374^{*} \\
(1.69)\end{array}$ & $\begin{array}{l}0.541^{\star \star \star} \\
(2.86)\end{array}$ & $\begin{array}{l}0.434^{\star \star} \\
(2.25)\end{array}$ & $\begin{array}{c}0.272 \\
(1.12)\end{array}$ & $\begin{array}{r}0.090 \\
(0.39)\end{array}$ & $\begin{array}{c}0.308 \\
(1.57)\end{array}$ \\
\hline Loser & $\begin{array}{l}1.857^{\star * \star} \\
(8.39)\end{array}$ & $\begin{array}{l}1.642^{\star \star \star} \\
(5.48)\end{array}$ & $\begin{array}{l}1.038^{\star \star \star} \\
(3.86)\end{array}$ & $\begin{array}{l}1.683^{\star \star \star} \\
(7.80)\end{array}$ & $\begin{array}{l}1.678^{\star \star \star} \\
(7.40)\end{array}$ & $\begin{array}{l}1.345^{\star * *} \\
(4.55)\end{array}$ & $\begin{array}{l}0.811^{\star \star \star} \\
(3.23)\end{array}$ & $\begin{array}{l}1.452^{\star \star \star} \\
(6.68)\end{array}$ \\
\hline 2 & $\begin{array}{l}0.490^{\star *} \\
(2.07)\end{array}$ & $\begin{array}{l}0.463^{*} \\
(1.87)\end{array}$ & $\begin{array}{l}0.373^{*} \\
(1.68)\end{array}$ & $\begin{array}{l}0.442^{\star \star} \\
(2.26)\end{array}$ & $\begin{array}{c}0.314 \\
(1.25)\end{array}$ & $\begin{array}{r}0.201 \\
(0.78)\end{array}$ & $\begin{array}{r}0.161 \\
(0.66)\end{array}$ & $\begin{array}{c}0.263 \\
(1.29)\end{array}$ \\
\hline 3 & $\begin{array}{l}0.218 \\
(1.11)\end{array}$ & $\begin{array}{l}0.613^{\star \star} \\
(2.54)\end{array}$ & $\begin{array}{l}0.402^{*} \\
(1.78)\end{array}$ & $\begin{array}{l}0.385^{\star *} \\
(2.05)\end{array}$ & $\begin{array}{r}0.070 \\
(0.34)\end{array}$ & $\begin{array}{l}0.422^{\star} \\
(1.67)\end{array}$ & $\begin{array}{c}0.123 \\
(0.53)\end{array}$ & $\begin{array}{c}0.212 \\
(1.07)\end{array}$ \\
\hline 4 & $\begin{array}{l}0.006 \\
(0.03)\end{array}$ & $\begin{array}{c}0.243 \\
(0.94)\end{array}$ & $\begin{array}{r}0.047 \\
(0.18)\end{array}$ & $\begin{array}{l}-0.024 \\
(-0.12)\end{array}$ & $\begin{array}{l}-0.205 \\
(-0.85)\end{array}$ & $\begin{array}{l}-0.037 \\
(-0.13)\end{array}$ & $\begin{array}{l}-0.252 \\
(-0.95)\end{array}$ & $\begin{array}{l}-0.256 \\
(-1.17)\end{array}$ \\
\hline Winner & $\begin{array}{l}-0.282 \\
(-1.17)\end{array}$ & $\begin{array}{l}0.517^{\star} \\
(1.84)\end{array}$ & $\begin{array}{r}0.017 \\
(0.07)\end{array}$ & $\begin{array}{l}-0.069 \\
(-0.32)\end{array}$ & $\begin{array}{l}-0.431^{*} \\
(-1.69)\end{array}$ & $\begin{array}{c}0.252 \\
(0.85)\end{array}$ & $\begin{array}{l}-0.222 \\
(-0.85)\end{array}$ & $\begin{array}{l}-0.289 \\
(-1.26)\end{array}$ \\
\hline LMW & $\begin{array}{l}2.139^{* * *} \\
(7.30)\end{array}$ & $\begin{array}{l}1.126^{\star \star \star} \\
(3.81)\end{array}$ & $\begin{array}{l}1.021^{\text {*** }} \\
(3.58)\end{array}$ & $\begin{array}{l}1.752^{\star * *} \\
(7.46)\end{array}$ & $\begin{array}{l}2.109^{\star \star \star} \\
(7.12)\end{array}$ & $\begin{array}{l}1.093^{* * *} \\
(3.58)\end{array}$ & $\begin{array}{l}1.034^{\star \star \star} \\
(4.02)\end{array}$ & $\begin{array}{l}1.741^{* \star \star} \\
(7.55)\end{array}$ \\
\hline
\end{tabular}

Panel B. Returns to Contrarian Investment Strategies and Past 3-Month Returns (1980-1999)

\begin{tabular}{|c|c|c|c|c|c|c|c|c|}
\hline \multirow{3}{*}{$\begin{array}{c}\text { Rank of Past } \\
\text { 3-Month Returns }\end{array}$} & \multicolumn{4}{|c|}{ Returns } & \multicolumn{4}{|c|}{ 4-Factor Adjusted Returns } \\
\hline & \multicolumn{3}{|c|}{ Firm Size } & \multirow[b]{2}{*}{ All } & \multicolumn{3}{|c|}{ Firm Size } & \multirow[b]{2}{*}{ All } \\
\hline & Micro & Small & Big & & Micro & Small & Big & \\
\hline All & $\begin{array}{l}0.557^{* \star *} \\
(2.81)\end{array}$ & $\begin{array}{l}0.593^{\star \star} \\
(2.55)\end{array}$ & $\begin{array}{l}0.530^{* *} \\
(2.52)\end{array}$ & $\begin{array}{l}0.546^{\star \star \star} \\
(2.88)\end{array}$ & $\begin{array}{l}0.440^{\star \star} \\
(2.12)\end{array}$ & $\begin{array}{c}0.369 \\
(1.47)\end{array}$ & $\begin{array}{c}0.368 \\
(1.52)\end{array}$ & $\begin{array}{l}0.403^{\star *} \\
(2.00)\end{array}$ \\
\hline Loser & $\begin{array}{l}2.240^{* * *} \\
(8.69)\end{array}$ & $\begin{array}{l}1.918^{\star \star \star} \\
(5.47)\end{array}$ & $\begin{array}{l}1.479^{* * *} \\
(5.86)\end{array}$ & $\begin{array}{l}2.010^{\star * \star} \\
(8.23)\end{array}$ & $\begin{array}{l}2.100^{\star \star \star} \\
(7.85)\end{array}$ & $\begin{array}{l}1.720^{\star \star *} \\
(4.95)\end{array}$ & $\begin{array}{l}1.339^{\star \star \star} \\
(4.96)\end{array}$ & $\begin{array}{l}1.844^{* * *} \\
(7.45)\end{array}$ \\
\hline 2 & $\begin{array}{l}0.466 \\
(1.64)\end{array}$ & $\begin{array}{l}0.642^{\star \star} \\
(2.20)\end{array}$ & $\begin{array}{l}0.664^{\star \star \star} \\
(2.92)\end{array}$ & $\begin{array}{l}0.523^{\star \star} \\
(2.28)\end{array}$ & $\begin{array}{c}0.316 \\
(1.08)\end{array}$ & $\begin{array}{c}0.392 \\
(1.33)\end{array}$ & $\begin{array}{l}0.523^{\star \star} \\
(2.08)\end{array}$ & $\begin{array}{c}0.368 \\
(1.62)\end{array}$ \\
\hline 3 & $\begin{array}{c}0.023 \\
(0.10)\end{array}$ & $\begin{array}{l}0.790^{\star \star \star} \\
(2.95)\end{array}$ & $\begin{array}{l}0.593^{* *} \\
(2.41)\end{array}$ & $\begin{array}{c}0.295 \\
(1.41)\end{array}$ & $\begin{array}{l}-0.037 \\
(-0.16)\end{array}$ & $\begin{array}{l}0.695^{\star \star} \\
(2.55)\end{array}$ & $\begin{array}{c}0.357 \\
(1.34)\end{array}$ & $\begin{array}{c}0.162 \\
(0.77)\end{array}$ \\
\hline 4 & $\begin{array}{l}-0.244 \\
(-1.00)\end{array}$ & $\begin{array}{l}0.457^{\star} \\
(1.74)\end{array}$ & $\begin{array}{c}0.242 \\
(0.91)\end{array}$ & $\begin{array}{c}0.010 \\
(0.05)\end{array}$ & $\begin{array}{l}-0.381 \\
(-1.43)\end{array}$ & $\begin{array}{l}0.208 \\
(0.74)\end{array}$ & $\begin{array}{c}0.018 \\
(0.07)\end{array}$ & $\begin{array}{l}-0.120 \\
(-0.54)\end{array}$ \\
\hline Winner & $\begin{array}{l}-0.510^{\star *} \\
(-2.12)\end{array}$ & $\begin{array}{r}0.277 \\
(0.86)\end{array}$ & $\begin{array}{c}0.104 \\
(0.37)\end{array}$ & $\begin{array}{l}-0.251 \\
(-1.14)\end{array}$ & 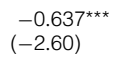 & $\begin{array}{c}0.058 \\
(0.17)\end{array}$ & $\begin{array}{l}-0.049 \\
(-0.17)\end{array}$ & $\begin{array}{l}-0.420^{*} \\
(-1.85)\end{array}$ \\
\hline LMW & $\begin{array}{l}2.750^{\star * *} \\
(8.85)\end{array}$ & $\begin{array}{l}1.641^{\star \star \star} \\
(4.68)\end{array}$ & 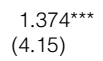 & $\begin{array}{l}2.261^{\star \star \star} \\
(8.62)\end{array}$ & $\begin{array}{l}2.738^{\star \star \star} \\
(8.95)\end{array}$ & $\begin{array}{l}1.662^{\star \star \star} \\
(4.68)\end{array}$ & $\begin{array}{l}1.387^{\text {} \star \star \star ~} \\
(4.35)\end{array}$ & $\begin{array}{l}2.263^{\star \star \star} \\
(9.23)\end{array}$ \\
\hline
\end{tabular}


TABLE 1 (continued)

Returns to Contrarian Investment Strategies: Effect of Past 3-Month Returns

Panel C. Returns to Contrarian Investment Strategies and Past 3-Month Returns (2000-2011)

\begin{tabular}{|c|c|c|c|c|c|c|c|c|}
\hline \multirow{3}{*}{$\begin{array}{c}\text { Rank of Past } \\
\text { 3-Month Returns }\end{array}$} & \multicolumn{4}{|c|}{ Returns } & \multicolumn{4}{|c|}{ 4-Factor Adjusted Returns } \\
\hline & \multicolumn{3}{|c|}{ Firm Size } & \multirow[b]{2}{*}{ All } & \multicolumn{3}{|c|}{ Firm Size } & \multirow[b]{2}{*}{ All } \\
\hline & Micro & Small & Big & & Micro & Small & Big & \\
\hline All & $\begin{array}{l}0.741^{* *} \\
(2.17)\end{array}$ & $\begin{array}{c}0.495 \\
(1.07)\end{array}$ & $\begin{array}{l}0.115 \\
(0.25)\end{array}$ & $\begin{array}{c}0.532 \\
(1.43)\end{array}$ & $\begin{array}{l}0.635^{\star \star} \\
(2.00)\end{array}$ & $\begin{array}{r}0.401 \\
(0.96)\end{array}$ & $\begin{array}{l}0.026 \\
(0.06)\end{array}$ & $\begin{array}{c}0.479 \\
(1.38)\end{array}$ \\
\hline Loser & $\begin{array}{l}1.221^{\star \star *} \\
(3.22)\end{array}$ & $\begin{array}{l}1.183^{\star *} \\
(2.21)\end{array}$ & $\begin{array}{l}0.302 \\
(0.54)\end{array}$ & $\begin{array}{l}1.139^{\star \star \star} \\
(2.91)\end{array}$ & $\begin{array}{l}1.221^{\star \star \star} \\
(3.08)\end{array}$ & $\begin{array}{l}1.027^{\star} \\
(1.86)\end{array}$ & $\begin{array}{c}0.488 \\
(1.13)\end{array}$ & $\begin{array}{l}1.254^{\star \star \star} \\
(3.02)\end{array}$ \\
\hline 2 & $\begin{array}{c}0.531 \\
(1.41)\end{array}$ & $\begin{array}{c}0.164 \\
(0.37)\end{array}$ & $\begin{array}{l}-0.112 \\
(-0.25)\end{array}$ & $\begin{array}{c}0.308 \\
(0.92)\end{array}$ & $\begin{array}{c}0.447 \\
(1.14)\end{array}$ & $\begin{array}{c}0.184 \\
(0.40)\end{array}$ & $\begin{array}{l}-0.038 \\
(-0.07)\end{array}$ & $\begin{array}{r}0.357 \\
(1.08)\end{array}$ \\
\hline 3 & $\begin{array}{l}0.542^{*} \\
(1.72)\end{array}$ & $\begin{array}{r}0.317 \\
(0.72)\end{array}$ & $\begin{array}{c}0.083 \\
(0.20)\end{array}$ & $\begin{array}{c}0.536 \\
(1.55)\end{array}$ & $\begin{array}{r}0.517 \\
(1.50)\end{array}$ & $\begin{array}{r}0.250 \\
(0.58)\end{array}$ & $\begin{array}{c}0.033 \\
(0.09)\end{array}$ & $\begin{array}{c}0.568 \\
(1.52)\end{array}$ \\
\hline 4 & $\begin{array}{c}0.423 \\
(1.12)\end{array}$ & $\begin{array}{l}-0.114 \\
(-0.23)\end{array}$ & $\begin{array}{l}-0.277 \\
(-0.53)\end{array}$ & $\begin{array}{l}-0.081 \\
(-0.22)\end{array}$ & $\begin{array}{c}0.290 \\
(0.82)\end{array}$ & $\begin{array}{l}-0.312 \\
(-0.73)\end{array}$ & $\begin{array}{l}-0.417 \\
(-0.94)\end{array}$ & $\begin{array}{l}-0.189 \\
(-0.57)\end{array}$ \\
\hline Winner & $\begin{array}{c}0.098 \\
(0.22)\end{array}$ & $\begin{array}{l}0.916^{*} \\
(1.80)\end{array}$ & $\begin{array}{l}-0.129 \\
(-0.27)\end{array}$ & $\begin{array}{c}0.236 \\
(0.58)\end{array}$ & $\begin{array}{c}0.118 \\
(0.25)\end{array}$ & $\begin{array}{r}0.841 \\
(1.53)\end{array}$ & $\begin{array}{l}-0.313 \\
(-0.74)\end{array}$ & $\begin{array}{c}0.194 \\
(0.46)\end{array}$ \\
\hline LMW & $\begin{array}{l}1.122^{\star *} \\
(2.14)\end{array}$ & $\begin{array}{r}0.267 \\
(0.54)\end{array}$ & $\begin{array}{c}0.432 \\
(0.92)\end{array}$ & $\begin{array}{l}0.903^{\star *} \\
(2.32)\end{array}$ & $\begin{array}{l}1.103^{\text {** }} \\
(2.00)\end{array}$ & $\begin{array}{r}0.187 \\
(0.34)\end{array}$ & $\begin{array}{l}0.801^{*} \\
(1.79)\end{array}$ & $\begin{array}{l}1.060^{* *} \\
(2.37)\end{array}$ \\
\hline
\end{tabular}

of $1.68 \%$ per month $(t$-statistic $=7.80)$ for stocks that are $3 \mathrm{M}$ extreme losers. The reversal profits are virtually 0 for the $3 \mathrm{M}$ winner stocks, and the difference between the contrarian profits generated by the $3 \mathrm{M}$ loser stocks and $3 \mathrm{M}$ winner stocks is highly significant $(t$-statistic $=7.46)$. The economic and statistical significance are similar when we adjust for exposure to the 4 common risk factors.

Panel A of Table 1 reports additional tests that examine how these results relate to the market capitalizations of the stocks. As Panel A shows, the results are stronger for microcaps, but we find significant reversals among the $3 \mathrm{M}$ losers for small and big firms as well. In contrast, there is no evidence of contrarian profits for any of the size groups for stocks that are $3 \mathrm{M}$ winners.

The U.S. equity market underwent substantial structural changes in the past decade, which eroded the barriers to entry in the business of supplying liquidity. These structural changes (see, e.g., Chordia, Roll, and Subrahmanyam (2011), Chordia, Subrahmanyam, and Tong (2014)) include the introduction of decimalization, greater participation of hedge funds and other informed institutional investors, and a sharp increase in high-frequency traders who have largely replaced the traditional liquidity providers, such as NYSE specialists and NASDAQ market makers. To examine the impact of these changes on the return reversals, we split our sample into two subperiods: 1980-1999 and 2000-2011. We expect the increase in the competition for liquidity provision to have a negative impact on contrarian profits and possibly attenuate the effect of past returns.

As shown in Panels B and C of Table 1, the profitability of the contrarian strategy that employs all stocks is much lower in the post-2000 period, but it is highest for $3 \mathrm{M}$ loser stocks in both subperiods. For the $3 \mathrm{M}$ losers, the average risk-adjusted contrarian profit is $1.84 \%$ in the 1980-1999 period, which declines to $1.25 \%$ in the recent period. The decline in return reversals is especially large for the big firms, which realize an average reversal profit of $1.34 \%$ in the earlier 
subperiod but only $0.49 \%$ in the recent decade. These findings are consistent with the increased market-making capacity during the recent period. ${ }^{8,9}$

\section{Prior Stock Returns and Changes in Active Institutions}

We argue that stocks with low past returns are associated with stronger reversals because these stocks experience a drop in participation by the active institutions that are likely to be liquidity providers. We start the analysis by investigating the behavior of active institutions that are required to report their holdings in $13 \mathrm{~F}$ filings. Our focus is on institutions that are active (ACTIVE) or churn their portfolios actively (SHORT_TERM) based on the notion that active institutions are more likely to be liquidity providers.

Past stock returns may influence the participation of active investors for several reasons. Active institutional investors holding stocks that performed badly in the past may face withdrawals, and as a result, they may be forced to sell some of their stocks. Additionally, stocks may become less desirable for active institutions when their market capitalization drops for window-dressing reasons (they do not want to be associated with losers). ${ }^{10}$ Finally, the exit of active (institutional and noninstitutional) investors and past returns may be linked through behavioral arguments. For example, active individuals and institutions can be susceptible to the extrapolation bias described by Barberis, Shleifer, and Vishny (1998) and the self-attribution bias described by Daniel, Hirshleifer, and Subrahmanyam (1998), which could lead them to sell losers. These arguments motivate our examination of active institutions linking past returns and monthly reversal profits.

We first document the relation between stock returns and institutional ownership by sorting stocks into quintiles based on the cumulative 3-month stock returns from months $t-3$ to $t-1$ (3M). For the stocks in each of these quintiles, we report the level and changes in the number of active institutional investors, defined as ACTIVE or SHORT_TERM institutions. In each case, we report the level (in month $t-1$ ) and changes in these measures over the months $t-3$ to $t-1$ based on the latest information during the quarter.

As shown in Table 2, there appear to be fewer active institutional investors holding stocks that experience extreme returns. We observe a lower number

\footnotetext{
${ }^{8}$ In unreported results, we find that there is a substantial increase in the number of active institutions (including hedge funds) in the post-2000 period. We also find that exits of these hedge funds are more sensitive to $3 \mathrm{M}$ losers in the 1980-1999 period than in the post-2000 period.

${ }^{9}$ We also find that frictions in market prices, such as bid-ask bounce, do not drive our central findings. Specifically, when we skip a week between formation and holding months in the contrarian strategy, we get qualitatively similar results. In particular, all of the profit figures in Table 1 remain significant, except for big firms in the second subperiod. Results are available from the authors.

${ }^{10}$ Because the stock's return is at least partially unpredictable, conditioning on this variable also addresses the endogeneity issue that arises when conditioning on institutional exits (i.e., institutions may exit prior to periods of anticipated illiquidity). Indeed, as mentioned earlier, our results also hold after controlling for momentum, a primary source of return predictability. We note, however, that the stock's past return may become a coordinating variable that causes investors' exits. For example, within the context of the herding models of Froot, Scharfstein, and Stein (1992) and Hirshleifer, Subrahmanyam, and Titman (1994), there are situations where investors optimally choose to coordinate their choices of which stocks to evaluate. In this setting, it is natural to have fewer active investors following stocks that show reductions in market capitalization because of the belief that firms with low market capitalizations are less liquid, which becomes self-fulfilling because of the exit of active investors.
} 
TABLE 2

Past 3-Month Stock Returns and Active Institutions

\begin{tabular}{|c|c|c|c|c|}
\hline $\begin{array}{c}\text { Rank of Past } \\
\text { 3-Month Returns }\end{array}$ & ACTIVE & $\triangle \mathrm{ACTIVE}$ & SHORT_TERM & $\triangle S H O R T$ TERM \\
\hline Loser & 44.610 & $\begin{array}{l}-1.743^{\text {}} \\
(-4.98)\end{array}$ & 53.448 & $\begin{array}{l}-1.318^{\text {** }} \\
(-3.84)\end{array}$ \\
\hline 2 & 54.867 & $\begin{array}{l}-0.071 \\
(-0.36)\end{array}$ & 61.106 & $\begin{array}{c}0.154 \\
(0.61)\end{array}$ \\
\hline 3 & 58.630 & $\begin{array}{l}0.970^{\star \star \star} \\
(6.08)\end{array}$ & 64.356 & $\begin{array}{l}0.968^{\star \star \star} \\
(3.99)\end{array}$ \\
\hline 4 & 59.179 & $\begin{array}{l}2.223^{\star \star \star} \\
(11.41)\end{array}$ & 65.558 & $\begin{array}{l}2.109^{\star \star \star} \\
(8.69)\end{array}$ \\
\hline Winner & 48.150 & $\begin{array}{l}4.194^{\star \star \star} \\
(9.79)\end{array}$ & 56.612 & $\begin{array}{l}4.306^{\star \star \star} \\
(12.29)\end{array}$ \\
\hline LMW & & $\begin{array}{l}-5.936^{\star \star \star} \\
(-8.48)\end{array}$ & & $\begin{array}{l}-5.624^{\star \star \star} \\
(-10.29)\end{array}$ \\
\hline
\end{tabular}

of institutions holding 3M loser and winner stocks across both investor categories. More importantly, although active institutional participation declines for $3 \mathrm{M}$ loser stocks, there is a general increase in the number of institutions holding stocks in most of the other $3 \mathrm{M}$ groups. Indeed, we observe a fall in ACTIVE and SHORT_TERM among the 3M losers, and the decline is significantly lower than the corresponding numbers in the $3 \mathrm{M}$ winner stocks. Hence, the numbers in Table 2 indicate a strong positive relation between $3 \mathrm{M}$ stock returns and changes in the participation of active institutions over the same quarter.

\section{Monthly Return Reversals and Institutional Exits}

Our arguments predict that the magnitude of reversals is affected by the presence of active investors. Ceteris paribus, an increase (decrease) in the number of such investors should decrease (increase) the magnitude of the stock's return reversals. For our initial test of this proposition, we examine changes in the number of active institutional investors for each stock, proxied by $\triangle$ ACTIVE. Specifically, we separately examine the return patterns for two groups of stocks: those that experience a decline in number of active investors over the quarter prior to month $t-1$ and those that do not. As Figure 1 illustrates, we measure the change in the number of institutional owners over months $t-3$ to $t-1$ and evaluate contrarian profits across the portfolio formation month, month $t$, and the holding period, month $t+1$.

Panel A of Table 3 shows that return reversals are stronger following a decrease in the number of active institutions. For the sample of all stocks, the riskadjusted contrarian strategy yields a significant $0.55 \%$ per month when there is a decline in active institutions, whereas the returns are insignificant at $0.14 \%$ for firms that have an increase in active institutional investors. The risk-adjusted contrarian profit is significantly higher for the group of stocks that experience a drop in the number of active institutional owners compared with the stocks that have 
TABLE 3

Returns to Contrarian Investment Strategies: Effect of Changes in Active Investors

In Table 3, stocks are sorted into the 3 size groups of microcaps, small stocks, and big stocks, using the NYSE 20th and 50th percentiles as breakpoints. Within each size group, stocks are independently sorted into $2 \times 5$ portfolios according to whether there is a decrease or increase in the number of active institutions (classified following Abarbanell et al. (2003)) over the past 3 months, $t-3$ to $t-1$ ( $\triangle$ ACTIVE), and 1-month stock returns $(t)$. The loser (winner) portfolio comprises the bottom (top) quintile of stocks. Panel A reports, for each subgroup of stocks according to change in the number of active institutions, the month $t+1$ (equal-weighted) profits attributable to the strategy of going long (short) with the 1-month loser (winner) stocks. Risk-adjusted returns are based on a 4-factor model comprising the 3 Fama-French (1993) factors (market, size, and book-to-market) and the Pástor-Stambaugh (2003) liquidity factor. The row "Decrease - Increase" reports the difference in profits between portfolios with a decrease in the number of active institutions and those with an increase. In Panel B, the active institutions are replaced with short-term institutions (Gaspar et al. (2005)). In Panel C, EXIT of active (short-term) institutions is further defined as occurring when there is a decrease in the number of active (short-term) institutions over the past 3 months and the number of active (short-term) institutions holding the stock is fewer than 10 in month $t-1$. Similarly, ENTRY of active (short-term) institutions is defined as occurring when there is an increase in the number of active (short-term) institutions over the past 3 months and the number of active (short-term) institutions holding the stock is fewer than 10 in month $t-3$. The row "EXIT - ENTRY" reports the difference in profits between portfolios with exit and entry of the active or short-term institutions. The Appendix provides detailed definitions of the variables. The sample period is 1980-2011. $t$-statistics adjusted using the Newey-West (1987) method are reported in parentheses. *, ${ }^{* *}$, and ${ }^{* * *}$ indicate significance at the $10 \%, 5 \%$, and $1 \%$ levels, respectively.

Panel A. Returns to Contrarian Investment Strategies and Change in Number of Active Institutions

\begin{tabular}{|c|c|c|c|c|c|c|c|c|}
\hline \multirow[b]{3}{*}{$\triangle$ ACTIVE } & \multicolumn{4}{|c|}{ Returns } & \multicolumn{4}{|c|}{ 4-Factor Adjusted Returns } \\
\hline & \multicolumn{3}{|c|}{ Firm Size } & \multirow[b]{2}{*}{ All } & \multicolumn{3}{|c|}{ Firm Size } & \multirow[b]{2}{*}{ All } \\
\hline & Micro & Small & Big & & Micro & Small & Big & \\
\hline Decrease & $\begin{array}{l}0.898^{\star \star \star} \\
(4.28)\end{array}$ & $\begin{array}{l}0.830^{\star * *} \\
(3.56)\end{array}$ & $\begin{array}{l}0.601^{\text {** }} \\
(2.48)\end{array}$ & $\begin{array}{l}0.796^{\star \star *} \\
(4.06)\end{array}$ & $\begin{array}{l}0.687^{\star \star \star *} \\
(3.26)\end{array}$ & $\begin{array}{l}0.541^{\text {** }} \\
(2.29)\end{array}$ & $\begin{array}{c}0.319 \\
(1.39)\end{array}$ & 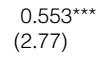 \\
\hline Increase & $\begin{array}{r}0.317 \\
(1.49)\end{array}$ & $\begin{array}{l}0.668^{\star * *} \\
(2.69)\end{array}$ & $\begin{array}{r}0.247 \\
(0.97)\end{array}$ & $\begin{array}{l}0.382^{*} \\
(1.87)\end{array}$ & $\begin{array}{c}0.132 \\
(0.58)\end{array}$ & $\begin{array}{r}0.357 \\
(1.49)\end{array}$ & $\begin{array}{l}-0.059 \\
(-0.22)\end{array}$ & $\begin{array}{c}0.135 \\
(0.63)\end{array}$ \\
\hline Decrease - Increase & $\begin{array}{l}0.581^{\star \star \star} \\
(3.71)\end{array}$ & $\begin{array}{c}0.162 \\
(0.91)\end{array}$ & $\begin{array}{l}0.354^{*} \\
(1.94)\end{array}$ & $\begin{array}{l}0.414^{\star * *} \\
(3.78)\end{array}$ & $\begin{array}{l}0.555^{\star \star \star} \\
(4.01)\end{array}$ & $\begin{array}{c}0.185 \\
(0.98)\end{array}$ & $\begin{array}{l}0.377^{\star \star} \\
(2.23)\end{array}$ & $\begin{array}{l}0.417^{\text {***}} \\
(4.14)\end{array}$ \\
\hline
\end{tabular}

Panel B. Returns to Contrarian Investment Strategies and Change in Number of Short-Term Institutions

\begin{tabular}{|c|c|c|c|c|c|c|c|c|}
\hline \multirow[b]{3}{*}{$\Delta$ SHORT_TERM } & \multicolumn{4}{|c|}{ Returns } & \multicolumn{4}{|c|}{ 4-Factor Adjusted Returns } \\
\hline & \multicolumn{3}{|c|}{ Firm Size } & \multirow[b]{2}{*}{ All } & \multicolumn{3}{|c|}{ Firm Size } & \multirow[b]{2}{*}{ All } \\
\hline & Micro & Small & Big & & Micro & Small & Big & \\
\hline Decrease & $\begin{array}{l}0.744^{\star \star \star} \\
(3.54)\end{array}$ & $\begin{array}{l}0.904^{\star \star \star} \\
(3.76)\end{array}$ & $\begin{array}{l}0.540^{\star \star} \\
(2.34)\end{array}$ & $\begin{array}{l}0.741^{\star \star \star} \\
(3.76)\end{array}$ & $\begin{array}{l}0.558^{\star \star} \\
(2.58)\end{array}$ & $\begin{array}{l}0.642^{\star \star \star} \\
(2.69)\end{array}$ & $\begin{array}{r}0.220 \\
(1.03)\end{array}$ & $\begin{array}{l}0.519^{\star \star \star \star} \\
(2.61)\end{array}$ \\
\hline Increase & $\begin{array}{l}0.379^{*} \\
(1.88)\end{array}$ & $\begin{array}{l}0.613^{\star \star} \\
(2.54)\end{array}$ & $\begin{array}{r}0.300 \\
(1.27)\end{array}$ & $\begin{array}{l}0.402^{\star *} \\
(2.07)\end{array}$ & $\begin{array}{c}0.190 \\
(0.87)\end{array}$ & $\begin{array}{c}0.277 \\
(1.17)\end{array}$ & $\begin{array}{c}0.029 \\
(0.12)\end{array}$ & $\begin{array}{c}0.157 \\
(0.76)\end{array}$ \\
\hline Decrease - Increase & $\begin{array}{l}0.364^{\star \star} \\
(2.41)\end{array}$ & $\begin{array}{l}0.291^{*} \\
(1.69)\end{array}$ & $\begin{array}{c}0.240 \\
(1.62)\end{array}$ & $\begin{array}{l}0.339^{\star \star \star} \\
(3.22)\end{array}$ & $\begin{array}{l}0.367^{\star \star} \\
(2.52)\end{array}$ & $\begin{array}{l}0.365^{\star *} \\
(2.06)\end{array}$ & $\begin{array}{c}0.190 \\
(1.33)\end{array}$ & $\begin{array}{l}0.363^{\text {***}} \\
(3.68)\end{array}$ \\
\hline
\end{tabular}

Panel C. Returns to Contrarian Investment Strategies and Institution Exit

\begin{tabular}{|c|c|c|c|c|}
\hline & \multicolumn{2}{|c|}{ Returns } & \multicolumn{2}{|c|}{ 4-Factor Adjusted Returns } \\
\hline & $\triangle$ ACTIVE & $\triangle \mathrm{SHORT}$ STERM & $\triangle \mathrm{ACTIVE}$ & $\Delta$ SHORT_TERM \\
\hline EXIT & $\begin{array}{l}1.018^{\star * *} \\
(3.50)\end{array}$ & $\begin{array}{l}1.329^{\star * *} \\
(4.12)\end{array}$ & $\begin{array}{l}0.946^{\text {*** }} \\
(3.04)\end{array}$ & $\begin{array}{l}1.227^{* * *} \\
(3.30)\end{array}$ \\
\hline ENTRY & $\begin{array}{c}0.172 \\
(0.60)\end{array}$ & $\begin{array}{c}0.212 \\
(0.80)\end{array}$ & $\begin{array}{l}-0.003 \\
(-0.01)\end{array}$ & $\begin{array}{c}0.132 \\
(0.48)\end{array}$ \\
\hline EXIT - ENTRY & $\begin{array}{l}0.846^{* * *} \\
(2.72)\end{array}$ & $\begin{array}{l}1.116^{\text {***}} \\
(3.35)\end{array}$ & $\begin{array}{l}0.949^{* \star *} \\
(3.32)\end{array}$ & $\begin{array}{l}1.095^{\text {** }} \\
(2.84)\end{array}$ \\
\hline
\end{tabular}

an increase in the number of active institutional investors. These findings continue to hold when we define active investors as those institutions that generate higher turnover, or SHORT_TERM. As shown in Panel B of Table 3, decreases in the number of SHORT_TERM investors in months $t-3$ to $t-1$ are associated with significant reversals of stock returns from $t$ to $t+1$. We do not find evidence of reversals for stocks with increases in SHORT_TERM. We obtain similar findings across size groupings: Risk-adjusted contrarian profits for small firms and 
microcaps are significant only when there are declines in the number of ACTIVE or SHORT_TERM. Although the evidence is weaker for large firms, it is noteworthy that none of the size groups displays return reversals when there are increases in the number of active institutions.

If exits by active institutions reduce the supply of liquidity, we ought to find stronger return reversals when the number of active investors declines to a small number following exits by these institutions. Similarly, we expect to find weak reversals with the entry of additional active institutions. We test this implication by first defining EXIT by active institutions in a particular stock in month $t-1$ as occurring when there is a decrease in the number of ACTIVE in the prior 3 months and the number of ACTIVE in month $t-1$ is fewer than 10. In a similar spirit, we define ENTRY of ACTIVE in a stock in month $t-1$ as occurring when there is an increase in the number of ACTIVE in the prior 3 months and the number of ACTIVE in month $t-3$ is fewer than 10. We construct the sample of EXIT and ENTRY of SHORT_TERM in an identical fashion.

The average contrarian profits associated with EXIT and ENTRY of active institutions are vastly different, as presented in Panel $\mathrm{C}$ of Table 3. The riskadjusted contrarian profits are highly significant for the case of exits of active investors, with average profits ranging from $0.95 \%$ to $1.23 \%$ per month. In contrast, we do not observe any reversals when the stocks experience an increase in active institutions, measured by either ACTIVE or SHORT_TERM. Overall, the findings in Tables 3 are in agreement with the notion that exits by active institutions affect the supply of liquidity and hence contribute materially to short-term return reversals.

These results also suggest that past stock returns provide a good proxy for changes in the number of active investors, and our arguments and findings suggest that low past returns may proxy for active investor exits better than institutional holdings data alone. This is not surprising because changes in the presence of institutional investors holding a stock as a proxy for active investors have drawbacks. First, institutional holdings are measured only at a quarterly frequency. As a result, the time lag between the observed changes in institutional holdings and the returns of the reversal strategy can be up to several months. Second, we argue that an increase in reversals emanates from shocks to the number of active investors; however, the change in institutional investors we observe can be partially anticipated. This reinforces our findings that use past stock returns (over the previous 3 months, as shown in Figure 1) as a proxy for changes in the number of LS investors that actively participate in a stock.

\section{E. Prior Stock Returns and Trading by LS Institutions}

Our arguments predict that the magnitude of reversals is affected by the presence of liquidity suppliers, which in turn varies with past returns. We provide additional analysis based on the identification of LS institutions in the Abel Noser database, following Anand et al. (2013). We examine the changes in the trading activities of LS institutions across stocks in the $3 \mathrm{M}$ return quintiles. LS institutions may withdraw from trading in $3 \mathrm{M}$ losers if these are smaller, more volatile stocks that require greater funding capital (Gromb and Vayanos (2002), Brunnermeier and Pedersen (2009), and Huang and Wang (2009)). 
We start by reporting the proportion of dollar trading volume of LS institutions in each of the $3 \mathrm{M}$ groups relative to all trades by LS institutions in month $t-4$, which is our benchmark period. Next, we compute the proportion of dollar trading volume of LS institutions in month $t$ (the formation period of the monthly reversal strategy) relative to the benchmark period. As stated by Anand et al. (2013), the relative proportion accounts for time-series variation in the trading activity. Consistent with our conjecture, Panel A of Table 4 shows a significant decrease in the trading by LS institutions in $3 \mathrm{M}$ loser stocks. We also observe a significantly larger relative proportion of trades by LS institutions in $3 \mathrm{M}$ winners. Our findings are unaffected if we change the benchmark period to the prior quarter (months $t-6$ to $t-4)$. Hence, Panel A of Table 4 provides direct evidence that $3 \mathrm{M}$ losers are associated with a decrease in the participation of LS institutions.

TABLE 4

Past 3-Month Stock Returns and LS Institutions

In Table 4, stocks are sorted into quintiles according to the 3-month ( $t-3$ to $t-1)$ accumulated stock returns. The loser (winner) portfolio comprises the bottom (top) quintile of stocks. Institutions are assigned into tercile portfolios based on TRADING_STYLE in month $t-4$ or over a 3 -month period between months $t-6$ and $t-4$, following Anand et al. (2013). The bottom-tercile institutions are classified as LS institutions. Panel A reports the equal-weighted daily averages of the relative proportion of dollar volume traded in a 3-month return quintile by LS institutions. The proportions are calculated relative to the benchmark period in month $t-4$ or over a 3 -month period between months $t-6$ and $t-4$, and the sample period is 1999-2011. The row "LMW" reports the difference in values between 3-month loser and winner portfolios. Panel $\mathrm{B}$ reports the average number of hedge funds in month $t-1$ and the change in the number of hedge funds between months $t-3$ and $t-1$. The sample period is 1980-2011. The Appendix provides detailed definitions of the variables. The row "LMW" reports the difference in values between 3-month loser and winner portfolios, and $t$-statistics adjusted using the Newey-West (1987) method are reported in parentheses. ${ }^{*},{ }^{* *}$, and ${ }^{* * *}$ indicate significance at the $10 \%, 5 \%$, and $1 \%$ levels, respectively.

Panel A. 3-Month Returns and Proportion of Dollar Trading Volume of LS Institutions

\begin{tabular}{|c|c|c|c|c|}
\hline $\begin{array}{c}\text { Rank of Past } \\
\text { 3-Month Returns } \\
\end{array}$ & $\underline{\text { VOLUME }_{t-4}}$ & $\frac{\text { VOLUME }_{t}}{\text { VOLUME }_{t-1}}-1$ & $\underline{\text { VOLUME }_{t-6: t-4}}$ & $\frac{\text { vOLUME }_{t}}{\text { VOLUME }_{t-6: t-1}}-1$ \\
\hline Loser & 0.192 & $\begin{array}{l}-0.067^{\star \star *} \\
(-3.02)\end{array}$ & 0.199 & $\begin{array}{l}-0.078^{\star \star \star} \\
(-3.29)\end{array}$ \\
\hline 2 & 0.235 & $\begin{array}{l}-0.050^{* \star *} \\
(-4.08)\end{array}$ & 0.232 & $\begin{array}{l}-0.057^{\text {}} \\
(-3.49)\end{array}$ \\
\hline 3 & 0.234 & $\begin{array}{l}-0.022 \\
(-1.43)\end{array}$ & 0.235 & $\begin{array}{l}-0.026 \\
(-1.54)\end{array}$ \\
\hline 4 & 0.214 & $\begin{array}{l}0.072^{\star \star \star} \\
(3.18)\end{array}$ & 0.220 & $\begin{array}{c}0.028 \\
(1.60)\end{array}$ \\
\hline Winner & 0.141 & $\begin{array}{l}0.328^{\star \star *} \\
(13.67)\end{array}$ & 0.150 & $\begin{array}{l}0.286^{\star \star \star} \\
(9.43)\end{array}$ \\
\hline LMW & & $\begin{array}{l}-0.395^{\star \star \star} \\
(-12.08)\end{array}$ & & $\begin{array}{l}-0.364^{\star \star \star} \\
(-10.59)\end{array}$ \\
\hline
\end{tabular}

Panel B. 3-Month Returns and Number of Hedge Funds $(t-1)$

\begin{tabular}{|c|c|c|}
\hline $\begin{array}{c}\text { Rank of Past } \\
\text { 3-Month Returns }\end{array}$ & HEDGE & $\Delta$ HEDGE \\
\hline Loser & 12.131 & $\begin{array}{l}-0.240^{\star \star} \\
(-2.26)\end{array}$ \\
\hline 2 & 13.936 & $\begin{array}{c}0.031 \\
(0.37)\end{array}$ \\
\hline 3 & 14.649 & $\begin{array}{l}0.196^{\star \star \star} \\
(2.91)\end{array}$ \\
\hline 4 & 14.959 & $\begin{array}{l}0.472^{\star \star \star} \\
(7.80)\end{array}$ \\
\hline Winner & 13.023 & $\begin{array}{l}1.187^{\text {** }} \\
(7.86)\end{array}$ \\
\hline LMW & & $\begin{array}{l}-1.427^{\star \star \star} \\
(-7.56)\end{array}$ \\
\hline
\end{tabular}




\section{F. Prior Stock Returns and Changes in Number of Hedge Funds}

In addition to our previous classification of ACTIVE and SHORT_TERM institutions, there is a growing literature suggesting that hedge funds play an important role in liquidity provision (Aragon (2007), Sadka (2010), Aragon and Strahan (2012), Franzoni and Plazzi (2013), and Jylhä, Rinne, and Suominen (2014)). For example, Franzoni and Plazzi (2013) use trade-level data and find that relative to other institutions, hedge fund trades improve stock liquidity, but their liquidity provision is more sensitive to funding shocks. Hence, we consider hedge funds as an alternative category of liquidity providers and examine whether hedge fund participation is related to past stock returns.

Our data on hedge fund holdings are constructed by matching the Thomson Reuters Institutional Holdings (13F) database with a manually collected list of the names of hedge fund companies. A detailed description of the hedge fund list is given by Agarwal, Jiang, Tang, and Yang (2013) and Agarwal, Fos, and Jiang (2013). ${ }^{11}$ To examine the relation between stock returns and hedge fund participation, we sort stocks into quintiles according to the $3 \mathrm{M}$ returns (months $t-3$ to $t-1$ ) and record the average number of hedge funds holding the stock, denoted as HEDGE. Panel B of Table 4 reports the average number of hedge funds in month $t-1$ and the change in the number of hedge funds ( $\triangle$ HEDGE) over the past quarter (months $t-3$ to $t-1$ ) in each quintile portfolio. The results exhibit a decrease in the number of hedge funds holding $3 \mathrm{M}$ loser stocks, whereas there is an increase in the number of hedge funds holding stocks in all other $3 \mathrm{M}$ groups. In addition, the decline in hedge funds among the $3 \mathrm{M}$ losers is significantly lower than that among the $3 \mathrm{M}$ winner stocks. Therefore, the results confirm the strong positive relation between $3 \mathrm{M}$ stock returns and changes in the participation of active institutions that are likely to be liquidity providers over the same quarter. ${ }^{12}$

\section{Alternative Explanations}

\section{A. Are the Reversals Due to Liquidity Demand Effects?}

This subsection reports the results of tests that examine whether shocks to the demand for liquidity can explain our results. We consider an alternative "fire sale" hypothesis, which suggests that a subset of past loser stocks will experience prolonged selling pressure, which gives rise to continued downward price pressure and a subsequent reversal. For example, Coval and Stafford (2007) show that mutual fund fire sales lead to material price pressures, and Lou (2012) finds that mutual fund flows have persistent price impacts. This line of reasoning indicates that $3 \mathrm{M}$ losers should experience greater trading activity than $3 \mathrm{M}$ winners, in particular by LD investors. Further, among the $3 \mathrm{M}$ losers, losers in the following month should show intense trading activity, and monthly contrarian profits should

\footnotetext{
${ }^{11}$ We thank Vikas Agarwal for generously sharing the data.

${ }^{12}$ In unreported results, we find that return reversals are stronger following a decrease in the number of hedge funds, consistent with the liquidity provision role of hedge funds (Franzoni and Plazzi (2013)). For example, the risk-adjusted contrarian strategy yields a significant $0.42 \%$ per month when there is a decline in hedge funds in the previous quarter, whereas firms with an increase in hedge funds record an insignificant contrarian profit of $0.12 \%$.
} 
emanate primarily from these $1 \mathrm{M}$ loser stocks. But we show, in fact, that these conjectures are not supported by the data. Thus, although we do not completely rule out the possibility that fire sales provide a partial explanation, our evidence suggests that liquidity demand shocks do not provide a complete explanation for our results.

The first piece of evidence on the changes in liquidity demand for the past losers comes from the trading behavior of LD institutions identified using the Abel Noser database, as explained in Section II.A. LD institutions are those that trade in the same direction as the stock returns and hence are likely to adopt trading styles that demand liquidity (Anand et al. (2013)). Panel A of Table 5 reports the relative proportion of dollar trading volume for LD institutions in stocks grouped by their $3 \mathrm{M}$ returns. We find a significant decrease of $13.7 \%$ in the trading by LD institutions for $3 \mathrm{M}$ losers in month $t$ (the contrarian strategy formation month) relative to the trading volume in month $t-4$ (the period before the $3 \mathrm{M}$ returns). Conversely, the relative proportional trading volume is significantly higher for the

\title{
TABLE 5
}

Past 3-Month Stock Returns, Volume, and Turnover

\begin{abstract}
In Panel A of Table 5, stocks are sorted into quintiles according to the 3-month ( $t-3$ to $t-1)$ accumulated stock returns. The loser (winner) portfolio comprises the bottom (top) quintile of stocks. Institutions are assigned into tercile portfolios based on TRADING_STYLE in month $t-4$ or over a 3 -month period between months $t-6$ and $t-4$, following Anand et al. (2013). The top-tercile institutions are classified as LD institutions. We report the equal-weighted daily averages of the relative proportion of dollar volume traded in a 3-month return quintile by LD institutions. The proportions are calculated relative to the benchmark period in month $t-4$ or over a 3 -month period between months $t-6$ and $t-4$, and the sample period is 1999-2011. In Panel B, stocks are independently sorted into quintiles according to their lagged 3-month accumulated returns $(t-3$ to $t-1)$ and 1 -month returns $(t)$ to generate $25(5 \times 5)$ portfolios. The loser (winner) portfolio comprises the bottom (top) quintile of stocks. For each of the 25 portfolios, we report the average daily stock abnormal turnover in month $t$ over the full sample from 1980 to 2011. The abnormal turnover is computed as stock turnover in month $t$ netting out the average turnover between months $t-12$ and $t-1$. The row "LMW" reports the difference in profits between 3-month loser and winner portfolios, and $t$-statistics adjusted using the Newey-West (1987) method are reported in parentheses. ${ }^{\star},{ }^{\star *}$, and ${ }^{\star \star \star}$ indicate significance at the $10 \%, 5 \%$, and $1 \%$ levels, respectively.
\end{abstract}

Panel A. 3-Month Returns and Proportion of Dollar Trading Volume of LD Institutions

\begin{tabular}{|c|c|c|c|c|}
\hline $\begin{array}{c}\text { Rank of Past } \\
\text { 3-Month Returns } \\
\end{array}$ & VOLUME $_{t-4}$ & $\frac{\text { VOLUME }_{t}}{\text { VOLUME }_{t-1}}-1$ & VOLUME $_{t-6: t-4}$ & $\frac{\text { VOLUME }_{t}}{\text { VOLUME }_{t-6: t-4}}-1$ \\
\hline Loser & 0.217 & $\begin{array}{l}-0.137^{\star \star \star} \\
(-4.04)\end{array}$ & 0.218 & $\begin{array}{l}-0.157^{\star \star \star} \\
(-5.07)\end{array}$ \\
\hline 2 & 0.227 & $\begin{array}{l}-0.053^{\star \star \star} \\
(-4.35)\end{array}$ & 0.232 & $\begin{array}{l}-0.079^{\star \star \star} \\
(-5.40)\end{array}$ \\
\hline 3 & 0.235 & $\begin{array}{l}-0.022 \\
(-1.58)\end{array}$ & 0.233 & $\begin{array}{l}-0.023 \\
(-1.60)\end{array}$ \\
\hline 4 & 0.219 & $\begin{array}{l}0.078^{\star \star \star} \\
(4.99)\end{array}$ & 0.221 & $\begin{array}{l}0.067^{\star \star \star} \\
(4.06)\end{array}$ \\
\hline Winner & 0.157 & $\begin{array}{l}0.427^{* * *} \\
(14.05)\end{array}$ & 0.162 & 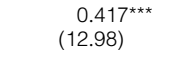 \\
\hline LMW & & $\begin{array}{l}-0.564^{* \star *} \\
(-13.36)\end{array}$ & & $\begin{array}{l}-0.574^{\star \star \star} \\
(-12.74)\end{array}$ \\
\hline
\end{tabular}

Panel B. 3-Month Returns and Stock Abnormal Turnover (relative to past 12 months, in \%)

\begin{tabular}{|c|c|c|c|c|c|c|}
\hline \multirow{2}{*}{$\begin{array}{c}\text { Rank of Past } \\
\text { 3-Month Returns }\end{array}$} & \multicolumn{6}{|c|}{ Rank of Past 1-Month Returns } \\
\hline & Loser & 2 & 3 & 4 & Winner & All \\
\hline Loser & 0.050 & -0.036 & -0.042 & -0.034 & 0.079 & 0.011 \\
\hline 2 & 0.025 & -0.034 & -0.036 & -0.026 & 0.079 & -0.002 \\
\hline 3 & 0.012 & -0.037 & -0.035 & -0.022 & 0.103 & -0.002 \\
\hline 4 & 0.012 & -0.036 & -0.031 & -0.010 & 0.128 & 0.008 \\
\hline Winner & 0.098 & 0.008 & 0.020 & 0.065 & 0.338 & 0.119 \\
\hline LMW & $\begin{array}{l}-0.048^{\star \star \star} \\
(-4.39)\end{array}$ & $\begin{array}{l}-0.044^{\star \star *} \\
(-7.55)\end{array}$ & $\begin{array}{l}-0.062^{\star \star \star} \\
(-13.20)\end{array}$ & $\begin{array}{l}-0.098^{\star \star \star} \\
(-17.04)\end{array}$ & $\begin{array}{l}-0.259^{\star \star \star} \\
(-13.28)\end{array}$ & $\begin{array}{l}-0.108^{\star \star \star} \\
(-11.51)\end{array}$ \\
\hline
\end{tabular}


$3 \mathrm{M}$ winner stocks by $42.7 \%$ relative to the benchmark period. The decrease in trading activity by LD institutions for the $3 \mathrm{M}$ losers indicates that these stocks do not experience greater demand for liquidity. Because we observe a decline in both LS and LD institutions, a stronger reversal in 3M losers is consistent with constraints in liquidity supply rather than an increase in liquidity demand.

For our analysis of trading activity, we independently sort stocks into quintiles based on stock returns over two periods: returns over the past quarter (i.e., $3 \mathrm{M}$ returns measured across months $t-3$ and $t-1$ ) and $1 \mathrm{M}$ returns during $t$. For each of the 25 portfolios, we compute the average abnormal daily stock turnover in month $t$, netting the corresponding daily turnover between months $t-12$ and $t-1 .^{13}$ The findings in Panel B of Table 5 show that the abnormal turnover for the $3 \mathrm{M}$ loser stocks is $0.01 \%$, significantly lower than the abnormal turnover for the $3 \mathrm{M}$ winner stocks, which is $0.12 \%$. This finding is inconsistent with the idea that low stock returns are associated with increased turnover (due to fire sales). Among the $1 \mathrm{M}$ losers, the $3 \mathrm{M}$ losers have lower abnormal turnover than $3 \mathrm{M}$ winners $(0.05 \%$ vs. $0.1 \%)$, and this difference is statistically significant. Finally, focusing on stocks that are $3 \mathrm{M}$ losers, the $1 \mathrm{M}$ losers are not more actively traded than the $1 \mathrm{M}$ winners. These results do not accord with the notion that reversal profits arise as a result of price pressure caused by prolonged heavy selling in response to low past returns.

We next examine whether our results are driven by the long or short legs of the contrarian strategy, and we also investigate whether reversals are driven by fire sales in down markets. Accordingly, we separately present returns to the long and short sides and for four market states corresponding to whether the valueweighted market return is positive (UP) or negative (DOWN) in the formation month $(t)$ and the holding month $(t+1)$. As we show in Panel B of Table 6, the risk-adjusted contrarian profit is concentrated in the $3 \mathrm{M}$ losers and primarily emanates from $1 \mathrm{M}$ winner stocks. Indeed, we find that the short leg of the strategy (based on $1 \mathrm{M}$ winners) yields significant risk-adjusted returns across all market states, ranging from $1.34 \%$ to $1.7 \%$ per month. On the other hand, the long position on $1 \mathrm{M}$ loser stocks (which are also $3 \mathrm{M}$ losers) does not generate significant risk-adjusted returns. These findings indicate that price pressure caused by fire sales in $3 \mathrm{M}$ and $1 \mathrm{M}$ losers is not a full explanation for contrarian profits, and the findings are consistent with the notion that fluctuations in liquidity supply form an important source of dynamic variation in contrarian profits. ${ }^{14}$

\section{B. Are the Reversals Due to Return Volatility Effects?}

Stocks that experience extreme negative returns are likely to be more volatile in the future, as described by Glosten et al. (1993), and it has been documented

\footnotetext{
${ }^{13}$ We obtain similar results when turnover is computed relative to the average in the previous 3 months, from $t-3$ to $t-1$.

${ }^{14}$ In a related paper, Da and Gao (2010) focus on why distressed stocks earn higher returns. They rationalize this phenomenon by showing that the subset of distressed stocks experiences low returns, institutional exits, and subsequent reversals, which they attribute to the clientele change. In contrast, we do not focus on distress but analyze monthly reversals in the full cross section by focusing on the role of longer-term returns. We show that, in fact, reversals are almost exclusively confined to those stocks that earn poor returns over the past 3 months.
} 
TABLE 6

Returns to Contrarian Investment Strategies Conditional on Market States

In Table 6, stocks are independently sorted into quintiles according to their lagged 3-month accumulated returns ( $t-3$ to $t-1)$ and 1 -month returns $(t)$ to generate 25 ( $5 \times 5)$ portfolios. The loser (winner) portfolio comprises the bottom (top) quintile of stocks. Panel A reports the month $t+1$ profits attributed to the strategy of going long (short) with the 1-month loser (winner) stocks conditional on market states in month $t$ or $t+1$. DOWN (UP) market state is recorded when the return on the value-weighted CRSP market index is negative (nonnegative), and the profits are reported for the full sample from 1980 to 2011. In Panel B, raw returns are further adjusted by a 4-factor model comprising the 3 Fama-French (1993) factors (market, size, and book-to-market) and the Pástor-Stambaugh (2003) liquidity factor. "LMW" reports the difference in profits between 3 -month loser and winner portfolios, and $t$-statistics adjusted using the Newey-West (1987) method are reported in parentheses. * **, and ${ }^{* \star *}$ indicate significance at the $10 \%, 5 \%$, and $1 \%$ levels, respectively.

Panel A. Returns to Contrarian Investment Strategies and Past 3-Month Returns

\begin{tabular}{|c|c|c|c|c|c|c|c|c|c|c|c|c|}
\hline \multirow{3}{*}{$\begin{array}{c}\text { Rank of Past } \\
\text { 3-Month Returns } \\
\end{array}$} & \multicolumn{12}{|c|}{ Rank of Past 1-Month Returns } \\
\hline & \multicolumn{3}{|c|}{ UP in Month $t$} & \multicolumn{3}{|c|}{ DOWN in Month $t$} & \multicolumn{3}{|c|}{ UP in Month $t+1$} & \multicolumn{3}{|c|}{ DOWN in Month $t+1$} \\
\hline & Loser & Winner & LMW & Loser & Winner & LMW & Loser & Winner & LMW & Loser & Winner & LMW \\
\hline Loser & $\begin{array}{l}2.227^{\text {** }} \\
(4.75)\end{array}$ & $\begin{array}{r}0.210 \\
(0.54)\end{array}$ & $\begin{array}{l}2.016^{\star \star \star} \\
(7.77)\end{array}$ & $\begin{array}{l}-0.268 \\
(-0.42)\end{array}$ & $\begin{array}{l}-1.408^{\text {*** }} \\
(-2.67)\end{array}$ & $\begin{array}{l}1.140^{* * *} \\
(3.58)\end{array}$ & $\begin{array}{l}5.537^{\star \star \star} \\
(11.10)\end{array}$ & $\begin{array}{l}2.851^{* * *} \\
(9.38)\end{array}$ & $\begin{array}{l}2.686^{\star \star \star} \\
(7.82)\end{array}$ & $\begin{array}{l}-5.665^{\text {*** }} \\
(-8.35)\end{array}$ & $\begin{array}{l}-5.712^{\star \star \star} \\
(-11.67)\end{array}$ & $\begin{array}{c}0.048 \\
(0.14)\end{array}$ \\
\hline 2 & $\begin{array}{l}2.010^{\star \star \star} \\
(5.52)\end{array}$ & $\begin{array}{l}1.372^{\star \star \star} \\
(4.42)\end{array}$ & $\begin{array}{l}0.638^{\star * *} \\
(2.97)\end{array}$ & $\begin{array}{c}0.002 \\
(0.00)\end{array}$ & $\begin{array}{l}-0.123 \\
(-0.26)\end{array}$ & $\begin{array}{c}0.124 \\
(0.35)\end{array}$ & $\begin{array}{l}4.553^{\star \star \star} \\
(13.45)\end{array}$ & $\begin{array}{l}3.537^{* * *} \\
(14.76)\end{array}$ & $\begin{array}{l}1.016^{\star \star \star} \\
(3.54)\end{array}$ & $\begin{array}{l}-4.145^{\text {*** }} \\
(-8.22)\end{array}$ & $\begin{array}{l}-3.652^{\star \star \star} \\
(-8.72)\end{array}$ & $\begin{array}{l}-0.493 \\
(-1.62)\end{array}$ \\
\hline 3 & $\begin{array}{l}2.033^{\star \star \star} \\
(5.99)\end{array}$ & $\begin{array}{l}1.418^{* \star *} \\
(4.75)\end{array}$ & $\begin{array}{l}0.615^{\star \star *} \\
(2.88)\end{array}$ & $\begin{array}{c}0.184 \\
(0.36)\end{array}$ & $\begin{array}{l}0.173 \\
(0.40)\end{array}$ & $\begin{array}{r}0.011 \\
(0.04)\end{array}$ & $\begin{array}{l}4.446^{\star \star \star} \\
(13.65)\end{array}$ & $\begin{array}{l}3.610^{* \star *} \\
(16.24)\end{array}$ & $\begin{array}{l}0.836^{\star \star \star} \\
(2.85)\end{array}$ & $\begin{array}{l}-3.750^{\text {*** }} \\
(-8.17)\end{array}$ & $\begin{array}{l}-3.401^{\star * *} \\
(-8.33)\end{array}$ & $\begin{array}{l}-0.349 \\
(-1.33)\end{array}$ \\
\hline 4 & $\begin{array}{l}1.763^{\star \star \star} \\
(5.14)\end{array}$ & $\begin{array}{l}1.485^{\star \star \star} \\
(4.59)\end{array}$ & $\begin{array}{c}0.279 \\
(1.34)\end{array}$ & $\begin{array}{l}-0.321 \\
(-0.59)\end{array}$ & $\begin{array}{c}0.197 \\
(0.39)\end{array}$ & $\begin{array}{l}-0.517 \\
(-1.34)\end{array}$ & $\begin{array}{l}4.141^{\star \star \star} \\
(14.05)\end{array}$ & $\begin{array}{l}3.725^{\star \star \star} \\
(13.63)\end{array}$ & $\begin{array}{c}0.416 \\
(1.42)\end{array}$ & $\begin{array}{l}-4.197^{\star \star \star} \\
(-8.53)\end{array}$ & $\begin{array}{l}-3.455^{\star \star \star} \\
(-8.77)\end{array}$ & $\begin{array}{l}-0.741^{\star \star} \\
(-2.60)\end{array}$ \\
\hline Winner & $\begin{array}{l}2.020^{\star \star \star} \\
(5.26)\end{array}$ & $\begin{array}{l}2.084^{\star \star \star} \\
(4.82)\end{array}$ & $\begin{array}{l}-0.064 \\
(-0.27)\end{array}$ & $\begin{array}{l}0.155 \\
(0.25)\end{array}$ & $\begin{array}{r}0.230 \\
(0.36)\end{array}$ & $\begin{array}{l}-0.075 \\
(-0.19)\end{array}$ & $\begin{array}{l}4.897^{\star \star \star} \\
(15.74)\end{array}$ & $\begin{array}{l}4.822^{\star \star \star} \\
(11.73)\end{array}$ & $\begin{array}{l}0.075 \\
(0.23)\end{array}$ & $\begin{array}{l}-4.536^{\star \star \star} \\
(-8.40)\end{array}$ & $\begin{array}{l}-4.233^{\star \star \star} \\
(-9.40)\end{array}$ & $\begin{array}{l}-0.303 \\
(-1.06)\end{array}$ \\
\hline \multirow[t]{2}{*}{ LMW } & $\begin{array}{c}0.207 \\
(0.77)\end{array}$ & $\begin{array}{l}-1.874^{\star \star \star} \\
(-7.12)\end{array}$ & $\begin{array}{l}2.081^{\star \star \star} \\
(7.00)\end{array}$ & $\begin{array}{l}-0.423 \\
(-1.35)\end{array}$ & $\begin{array}{l}-1.638^{\star \star \star} \\
(-4.13)\end{array}$ & $\begin{array}{l}1.215^{\star \star *} \\
(4.10)\end{array}$ & $\begin{array}{l}0.640^{\star} \\
(1.82)\end{array}$ & $\begin{array}{l}-1.971^{\star \star \star} \\
(-5.72)\end{array}$ & $\begin{array}{l}2.611^{\star \star \star} \\
(7.56)\end{array}$ & $\begin{array}{l}-1.129^{\star \star \star} \\
(-2.66)\end{array}$ & $\begin{array}{l}-1.479^{\star \star \star} \\
(-3.95)\end{array}$ & $\begin{array}{r}0.351 \\
(1.02)\end{array}$ \\
\hline & & & & & & & & & & & \multicolumn{2}{|c|}{ (continued on next page) } \\
\hline
\end{tabular}


TABLE 6 (continued)

Returns to Contrarian Investment Strategies Conditional on Market States

Panel B. Risk-Adjusted Returns to Contrarian Investment Strategies and Past 3-Month Returns

Rank of Past 1-Month Returns

\begin{tabular}{|c|c|c|c|c|c|c|c|c|c|c|c|c|}
\hline \multirow{2}{*}{$\begin{array}{c}\text { Rank of Past } \\
\text { 3-Month Returns }\end{array}$} & \multicolumn{3}{|c|}{ UP in Month $t$} & \multicolumn{3}{|c|}{ DOWN in Month $t$} & \multicolumn{3}{|c|}{ UP in Month $t+1$} & \multicolumn{3}{|c|}{ DOWN in Month $t+1$} \\
\hline & Loser & Winner & LMW & Loser & Winner & LMW & Loser & Winner & LMW & Loser & Winner & LMW \\
\hline Loser & $\begin{array}{c}0.159 \\
(0.59)\end{array}$ & $\begin{array}{l}-1.470^{\star \star \star} \\
(-8.82)\end{array}$ & $\begin{array}{l}1.628^{* * *} \\
(5.87)\end{array}$ & $\begin{array}{l}-0.547 \\
(-1.37)\end{array}$ & $\begin{array}{l}-1.695^{\star \star *} \\
(-8.83)\end{array}$ & $\begin{array}{l}1.148^{* * *} \\
(2.85)\end{array}$ & $\begin{array}{l}-0.704^{\star \star} \\
(-2.25)\end{array}$ & $\begin{array}{l}-1.575^{\star \star \star} \\
(-6.38)\end{array}$ & $\begin{array}{l}0.871^{\star \star} \\
(2.34)\end{array}$ & $\begin{array}{l}-0.106 \\
(-0.19)\end{array}$ & $\begin{array}{l}-1.341^{\star \star \star} \\
(-4.32)\end{array}$ & $\begin{array}{l}1.236^{\star \star} \\
(2.46)\end{array}$ \\
\hline 2 & $\begin{array}{c}0.322 \\
(1.65)\end{array}$ & $\begin{array}{l}-0.187 \\
(-1.38)\end{array}$ & $\begin{array}{l}0.508^{\star *} \\
(2.37)\end{array}$ & $\begin{array}{c}-0.341 \\
(-0.97)\end{array}$ & $\begin{array}{l}-0.503^{\text {*** }} \\
(-2.75)\end{array}$ & $\begin{array}{l}0.163 \\
(0.35)\end{array}$ & $\begin{array}{r}-0.341 \\
(-1.49)\end{array}$ & $\begin{array}{l}-0.266 \\
(-1.26)\end{array}$ & $\begin{array}{l}-0.075 \\
(-0.22)\end{array}$ & $\begin{array}{l}0.309 \\
(0.87)\end{array}$ & $\begin{array}{l}-0.310 \\
(-1.35)\end{array}$ & $\begin{array}{c}0.618 \\
(1.31)\end{array}$ \\
\hline 3 & $\begin{array}{l}0.380^{* *} \\
(2.46)\end{array}$ & $\begin{array}{l}-0.162 \\
(-1.35)\end{array}$ & $\begin{array}{l}0.541^{\star *} \\
(2.46)\end{array}$ & $\begin{array}{l}-0.118 \\
(-0.40)\end{array}$ & $\begin{array}{l}-0.170 \\
(-0.98)\end{array}$ & $\begin{array}{c}0.052 \\
(0.13)\end{array}$ & $\begin{array}{l}-0.245 \\
(-0.96)\end{array}$ & $\begin{array}{c}0.116 \\
(0.60)\end{array}$ & $\begin{array}{l}-0.361 \\
(-0.97)\end{array}$ & $\begin{array}{c}0.272 \\
(1.08)\end{array}$ & $\begin{array}{l}-0.173 \\
(-0.64)\end{array}$ & $\begin{array}{l}0.445 \\
(1.07)\end{array}$ \\
\hline 4 & $\begin{array}{l}0.136 \\
(0.97)\end{array}$ & $\begin{array}{l}-0.071 \\
(-0.60)\end{array}$ & $\begin{array}{c}0.208 \\
(1.02)\end{array}$ & $\begin{array}{l}-0.662^{\star \star} \\
(-2.38)\end{array}$ & $\begin{array}{c}0.002 \\
(0.01)\end{array}$ & $\begin{array}{l}-0.664 \\
(-1.27)\end{array}$ & $\begin{array}{l}-0.165 \\
(-0.67)\end{array}$ & $\begin{array}{c}0.291 \\
(1.40)\end{array}$ & $\begin{array}{l}-0.456 \\
(-1.20)\end{array}$ & $\begin{array}{l}0.146 \\
(0.55)\end{array}$ & $\begin{array}{l}-0.019 \\
(-0.05)\end{array}$ & $\begin{array}{l}0.165 \\
(0.31)\end{array}$ \\
\hline Winner & $\begin{array}{c}0.224 \\
(1.60)\end{array}$ & $\begin{array}{l}0.335^{\star} \\
(1.71)\end{array}$ & $\begin{array}{l}-0.112 \\
(-0.49)\end{array}$ & $\begin{array}{l}-0.029 \\
(-0.14)\end{array}$ & $\begin{array}{c}0.239 \\
(0.58)\end{array}$ & $\begin{array}{l}-0.268 \\
(-0.52)\end{array}$ & $\begin{array}{c}0.266 \\
(1.06)\end{array}$ & $\begin{array}{l}0.995^{\star * *} \\
(3.59)\end{array}$ & $\begin{array}{l}-0.729^{*} \\
(-1.84)\end{array}$ & $\begin{array}{c}0.138 \\
(0.47)\end{array}$ & $\begin{array}{l}-0.556 \\
(-1.43)\end{array}$ & $\begin{array}{c}0.694 \\
(1.52)\end{array}$ \\
\hline LMW & $\begin{array}{l}-0.065 \\
(-0.22)\end{array}$ & $\begin{array}{l}-1.805^{\star \star \star} \\
(-5.99)\end{array}$ & $\begin{array}{l}1.740^{* * *} \\
(5.76)\end{array}$ & $\begin{array}{l}-0.518 \\
(-1.34)\end{array}$ & $\begin{array}{l}-1.934^{* * *} \\
(-4.16)\end{array}$ & $\begin{array}{l}1.416^{* \star *} \\
(5.02)\end{array}$ & $\begin{array}{l}-0.970^{\star \star} \\
(-2.41)\end{array}$ & $\begin{array}{l}-2.570^{* \star *} \\
(-8.10)\end{array}$ & $\begin{array}{l}1.600^{\star \star \star} \\
(3.96)\end{array}$ & $\begin{array}{l}-0.244 \\
(-0.39)\end{array}$ & $\begin{array}{l}-0.786 \\
(-1.37)\end{array}$ & $\begin{array}{r}0.542 \\
(1.38)\end{array}$ \\
\hline
\end{tabular}


that monthly reversals are larger for more volatile stocks (Huang et al. (2010)). One potential reason for the latter result is that liquidity provision and arbitrage are riskier for stocks with greater return variations. We investigate whether the relation between past stock returns and contrarian profits can be explained by variation in stock return volatility. We do this by independently sorting stocks into quintiles according to their $3 \mathrm{M}$ returns (over months $t-3$ to $t-1$ ), $1 \mathrm{M}$ returns, and $1 \mathrm{M}$ return volatility during month $t$. The loser (winner) portfolio comprises the bottom (top) quintile of stocks. For each of the 25 portfolios sorted by past $3 \mathrm{M}$ returns and the $1 \mathrm{M}$ return volatility, we report the holding period $(t+1)$ riskadjusted contrarian profit in Panel A of Table 7.

\section{TABLE 7}

Returns to Contrarian Investment Strategies: Sorted by Past 3-Month Returns and Return Volatility

In Table 7, at the end of each month $t$, stocks are independently sorted into quintiles according to their accumulated 3 -month returns ( $t-3$ to $t-1)$, 1-month returns $(t)$, and 1 -month return volatility $(t)$. The loser (winner) portfolio comprises the bottom (top) quintile of stocks. Panel A reports, for each of the $25(5 \times 5)$ portfolios sorted by past 3-month returns and the 1-month return volatility, the equal-weighted risk-adjusted return in month $t+1$ attributable to the strategy of going long (short) with the 1-month loser (winner) stocks. The profits are reported for the full sample from 1980 to 2011. Risk-adjusted returns are based on a 4-factor model comprising the 3 Fama-French (1993) factors (market, size, and book-to-market) and the Pástor-Stambaugh (2003) liquidity factor. In Panel B, the return volatility is replaced with idiosyncratic return volatility in month $t$. The Appendix provides detailed definitions of the variables. The row "LMW" reports the difference in profits between 3-month loser and winner portfolios, and $t$-statistics adjusted using the Newey-West (1987) method are reported in parentheses. ${ }^{*},{ }^{* *}$, and ${ }^{* * *}$ indicate significance at the $10 \%, 5 \%$, and $1 \%$ levels, respectively.

Panel A. 4-Factor Adjusted Returns to Contrarian Investment Strategies Sorted by Past 3-Month Returns and Return Volatility

\begin{tabular}{|c|c|c|c|c|c|c|}
\hline \multirow{2}{*}{$\begin{array}{c}\text { Rank of Past } \\
\text { 3-Month Returns }\end{array}$} & \multicolumn{6}{|c|}{ Rank of Return Volatility } \\
\hline & Low & 2 & 3 & 4 & High & $\mathrm{HML}$ \\
\hline Loser & $\begin{array}{l}1.065^{\star \star} \\
(2.27)\end{array}$ & $\begin{array}{l}1.658^{\star \star \star} \\
(5.50)\end{array}$ & $\begin{array}{l}1.553^{\star \star \star} \\
(6.84)\end{array}$ & $\begin{array}{l}1.437^{\star \star \star} \\
(5.21)\end{array}$ & $\begin{array}{l}1.478^{* \star *} \\
(4.93)\end{array}$ & $\begin{array}{c}0.413 \\
(0.73)\end{array}$ \\
\hline 2 & $\begin{array}{l}0.642^{\star \star} \\
(2.57)\end{array}$ & $\begin{array}{l}0.515^{\star \star} \\
(2.18)\end{array}$ & $\begin{array}{l}0.765^{\star \star \star} \\
(3.34)\end{array}$ & $\begin{array}{l}0.453^{*} \\
(1.78)\end{array}$ & $\begin{array}{l}-0.070 \\
(-0.21)\end{array}$ & $\begin{array}{l}-0.712^{\star} \\
(-1.66)\end{array}$ \\
\hline 3 & $\begin{array}{c}0.145 \\
(0.54)\end{array}$ & $\begin{array}{l}1.014^{\star \star \star} \\
(4.91)\end{array}$ & $\begin{array}{l}0.625^{\text {** }} \\
(2.94)\end{array}$ & $\begin{array}{c}0.215 \\
(0.85)\end{array}$ & $\begin{array}{l}-0.261 \\
(-0.87)\end{array}$ & $\begin{array}{l}-0.406 \\
(-0.96)\end{array}$ \\
\hline 4 & $\begin{array}{l}-0.065 \\
(-0.19)\end{array}$ & $\begin{array}{l}0.715^{\star \star \star} \\
(3.25)\end{array}$ & $\begin{array}{r}0.297 \\
(1.35)\end{array}$ & $\begin{array}{l}-0.273 \\
(-1.21)\end{array}$ & $\begin{array}{l}-1.126^{\star * *} \\
(-3.68)\end{array}$ & $\begin{array}{l}-1.061^{\text {** }} \\
(-2.49)\end{array}$ \\
\hline Winner & $\begin{array}{c}0.093 \\
(0.24)\end{array}$ & $\begin{array}{l}1.132^{\star \star \star} \\
(3.05)\end{array}$ & $\begin{array}{l}0.438^{\star} \\
(1.77)\end{array}$ & $\begin{array}{l}-0.338^{\star} \\
(-1.66)\end{array}$ & $\begin{array}{l}-0.896^{\star \star *} \\
(-2.91)\end{array}$ & $\begin{array}{l}-0.989^{\star \star} \\
(-2.00)\end{array}$ \\
\hline LMW & $\begin{array}{l}0.972^{\star} \\
(1.67)\end{array}$ & $\begin{array}{c}0.526 \\
(1.32)\end{array}$ & $\begin{array}{l}1.115^{\star \star \star} \\
(3.44)\end{array}$ & $\begin{array}{l}1.775^{\star \star \star} \\
(5.93)\end{array}$ & $\begin{array}{l}2.374^{* \star *} \\
(7.34)\end{array}$ & \\
\hline
\end{tabular}

Panel B. 4-Factor Adjusted Returns to Contrarian Investment Strategies Sorted by Past 3-Month Returns and Idiosyncratic Volatility

\begin{tabular}{|c|c|c|c|c|c|c|}
\hline \multirow{2}{*}{$\begin{array}{c}\text { Rank of Past } \\
\text { 3-Month Returns } \\
\end{array}$} & \multicolumn{6}{|c|}{ Rank of Idiosyncratic Return Volatility } \\
\hline & Low & 2 & 3 & 4 & High & $\mathrm{HML}$ \\
\hline Loser & $\begin{array}{l}0.883^{*} \\
(1.74)\end{array}$ & $\begin{array}{l}1.240^{\star \star \star} \\
(4.08)\end{array}$ & $\begin{array}{l}1.627^{\star \star \star} \\
(6.68)\end{array}$ & 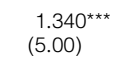 & $\begin{array}{l}1.436^{* \star *} \\
(5.11)\end{array}$ & $\begin{array}{c}0.552 \\
(0.95)\end{array}$ \\
\hline 2 & $\begin{array}{l}0.441^{*} \\
(1.88)\end{array}$ & $\begin{array}{l}0.600^{\star \star \star} \\
(2.87)\end{array}$ & $\begin{array}{l}0.548^{\star \star} \\
(2.22)\end{array}$ & $\begin{array}{l}0.555^{\star \star} \\
(2.37)\end{array}$ & $\begin{array}{l}-0.114 \\
(-0.34)\end{array}$ & $\begin{array}{l}-0.555 \\
(-1.34)\end{array}$ \\
\hline 3 & $\begin{array}{l}0.736^{\star \star \star} \\
(2.77)\end{array}$ & $\begin{array}{l}0.895^{\star \star \star} \\
(4.79)\end{array}$ & $\begin{array}{l}0.536^{\star \star} \\
(2.45)\end{array}$ & $\begin{array}{c}0.341 \\
(1.26)\end{array}$ & $\begin{array}{l}-0.464 \\
(-1.58)\end{array}$ & $\begin{array}{l}-1.200^{\star \star \star} \\
(-3.16)\end{array}$ \\
\hline 4 & $\begin{array}{c}0.237 \\
(0.75)\end{array}$ & $\begin{array}{l}0.518^{\star \star} \\
(2.02)\end{array}$ & $\begin{array}{c}0.365 \\
(1.50)\end{array}$ & $\begin{array}{l}-0.328 \\
(-1.45)\end{array}$ & $\begin{array}{l}-1.123^{* \star *} \\
(-4.03)\end{array}$ & $\begin{array}{l}-1.360^{\star \star \star} \\
(-3.76)\end{array}$ \\
\hline Winner & $\begin{array}{c}0.396 \\
(1.13)\end{array}$ & $\begin{array}{l}0.955^{\star \star \star} \\
(2.98)\end{array}$ & $\begin{array}{c}0.352 \\
(1.36)\end{array}$ & $\begin{array}{l}-0.160 \\
(-0.70)\end{array}$ & $\begin{array}{l}-1.046^{\star * *} \\
(-3.39)\end{array}$ & $\begin{array}{l}-1.442^{\star \star \star} \\
(-3.15)\end{array}$ \\
\hline LMW & $\begin{array}{r}0.487 \\
(0.76)\end{array}$ & $\begin{array}{c}0.285 \\
(0.68)\end{array}$ & $\begin{array}{l}1.276^{\star \star \star} \\
(4.25)\end{array}$ & $\begin{array}{l}1.500^{\text {** }} \\
(4.96)\end{array}$ & 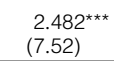 & \\
\hline
\end{tabular}


Several findings are worth noting. First, the contrarian profits are highly significant for $3 \mathrm{M}$ losers in all return volatility quintiles, with average monthly profits ranging from $1.07 \%$ to $1.66 \%$. Moreover, within the $3 \mathrm{M}$ loser stocks, the contrarian profits generated by the high-volatility stocks and low-volatility stocks are not significantly different. Second, for stocks with high volatility, a significant positive reversal payoff is recorded only in the $3 \mathrm{M}$ loser portfolio. In Panel B of Table 7, the volatility measure is based on the idiosyncratic return volatility component or IDIOVOL (see the Appendix for a detailed definition). The results are similar to those reported in Panel A, confirming that the strong influence of past stock returns on contrarian profits is not explained by the higher volatility among stocks with large declines in prices (or $3 \mathrm{M}$ losers). ${ }^{15}$

\section{Robustness Tests}

\section{A. Return Reversals Excluding January Months}

There is strong evidence of return reversals in the month of January (Jegadeesh (1990)), and tax-loss selling contributes to this turn-of-the-year effect (George and Hwang (2004)). To establish the robustness of our findings, we estimate the contrarian profits sorted on past $3 \mathrm{M}$ returns, excluding the holding period returns for the January months. In unreported results (available in Internet Appendix Table IA2), our main findings remain intact when we remove January from the sample. We find that reversal profits in the February to December months are concentrated in 3M losers for the sample of all stocks and the size-based sample, with non-January risk-adjusted profits ranging from $0.7 \%$ for large firms to $1.43 \%$ for microcaps. Moreover, there is no evidence of reversal profits in all other $3 \mathrm{M}$ return groups and across all size portfolios.

\section{B. Industry-Adjusted Reversals}

Recently, Hameed and Mian (2015) have shown that the monthly price reversal and, in turn, the return to providing liquidity are better identified using industry-adjusted returns, which presumably contain less noise arising from price reactions to public information and thus increase the signal coming from order imbalances. Specifically, they use deviations of monthly stock returns from the average return on the corresponding industry portfolio to sort stocks into winner and loser portfolios. Thus, as an alternative approach, we construct industry-adjusted contrarian portfolios by sorting stocks into loser and winner quintiles based on the industry-adjusted stock returns. Following Hameed and Mian (2015), we rely on the Fama and French (1997) system of classifying firms into 48 industries based on the 4-digit Standard Industrial Classification (SIC) codes.

In results reported in Internet Appendix Table IA3, we find that the industryadjusted contrarian profits are strongest for stocks that are past $3 \mathrm{M}$ losers. Across

\footnotetext{
${ }^{15}$ We note that there are significant negative reversal profits for the $3 \mathrm{M}$ winner portfolios of highvolatility stocks. It is possible that high-volatility winner stocks attract new investors (e.g., investors who prefer lottery-like features or overconfident investors), and the ensuing momentum dominates short-term reversals. The conditional monthly momentum is interesting, but we leave it for future research.
} 
all stocks and over the full sample period, the risk-adjusted profit for 3M losers is strikingly higher at $1.82 \%$ per month compared with an insignificant $0.22 \%$ for $3 \mathrm{M}$ winners. The results are similar within each size-sorted group: The riskadjusted profits are between $1 \%$ and $2.13 \%$ higher for $3 \mathrm{M}$ loser stocks compared with $3 \mathrm{M}$ winners. Similar to the earlier findings, the effect of previous $3 \mathrm{M}$ returns on monthly reversals continues to be present in the post-2000 period. Overall, the evidence provides reliable support for our contention that stock performance over the previous quarter proxies for exits by liquidity providers, which in turn predict stronger return reversals.

\section{Cross-Sectional Regression Analysis}

The extant literature highlights the role played by specific firm characteristics in predicting cross-sectional differences in return reversals. For example, Avramov et al. (2006) establish a significant link between short-term contrarian profits and stock illiquidity. They show that return reversals occur in stocks that have high illiquidity, consistent with price pressures from noninformational shocks being greater for illiquid stocks. The effect of stock illiquidity on reversals is consistent with our arguments because exits by active investors and market makers also affect illiquidity. Similar to Avramov et al. (2006), we use the Amihud (2002) measure (ILLIQ) as an empirical proxy for illiquidity. We find an inverse relation between the Amihud measure and past stock returns. Specifically, the $3 \mathrm{M}$ losers have the highest Amihud measure, and ILLIQ monotonically decreases for stocks that have performed increasingly better in the past 3 months. Also, the $3 \mathrm{M}$ losers experience an increase in illiquidity, whereas the $3 \mathrm{M}$ winners show a large decrease in illiquidity, as captured by the Amihud measure. ${ }^{16}$

In addition to cross-sectional differences in illiquidity, return reversals could be related to stock return volatility and turnover. Avramov et al. (2006) also find that monthly reversal profits are lower when the strategy is conditioned on stocks with high turnover. Because the Amihud proxy, turnover, and volatility are all related to unobserved (true) illiquidity, ${ }^{17}$ it is important to investigate how reversal profits are affected by our proxies for liquidity provision, namely, past returns and institutional exits, after controlling for the effects of the aforementioned firm characteristics.

We do this by considering the predictive effect of past $3 \mathrm{M}$ returns and changes in institutional ownership over the months $t-3$ to $t-1$ on return reversals across months $t$ and $t+1$, using the Fama-MacBeth (1973) regression approach. Specifically, we estimate the following cross-sectional regression in each month $t$ :

\footnotetext{
${ }^{16}$ In unreported results, we find that the average Amihud measure in month $t-1$ for the extreme losers over months $t-3$ to $t-1$ is $63 \%$ higher than that for the extreme quintile of winners over the same period. We also find that the $3 \mathrm{M}$ losers (winners) experience an increase (decrease) in the illiquidity measure of $31.3 \%(31.2 \%)$ in month $t-1$ relative to month $t-3$.

${ }^{17}$ See, respectively, Amihud (2002), Datar, Naik, and Radcliffe (1998), and Benston and Hagerman (1974).
} 


$$
\begin{aligned}
r_{i, t+1}= & \beta_{0}+\beta_{1} r_{i, t} \\
& +\beta_{2} \mathrm{D}\left(3 \mathrm{MLOSER}_{i, t-3: t-1}\right)+\beta_{3} r_{i, t} \mathrm{D}\left(3 \operatorname{MLOSER}_{i, t-3: t-1}\right) \\
& +\beta_{4} \mathrm{D}\left(\mathrm{NUM}_{i, t-3: t-1}^{-}\right)+\beta_{5} r_{i, t} \mathrm{D}_{\left(\mathrm{NUM}_{i, t-3: t-1}^{-}\right)} \\
& +\gamma_{1} \mathrm{ILLIQ}_{i, t}+\gamma_{2} r_{i, t} \mathrm{ILLIQ}_{i, t} \\
& +\gamma_{3} \mathrm{TURNOVER}_{i, t}+\gamma_{4} r_{i, t} \mathrm{TURNOVER}_{i, t} \\
& +\gamma_{5} \operatorname{VOLATILITY}_{i, t}+\gamma_{6} r_{i, t} \operatorname{VOLATILITY}_{i, t} \\
& +c^{\prime} \mathrm{CONTROLS}_{i, t}+\varepsilon_{i, t+1},
\end{aligned}
$$

where $r_{i, t}$ is the return on stock $i$ in month $t$, and $\mathrm{D}\left(3 \operatorname{MLOSER}_{i, t-3: t-1}\right)$ is a dummy variable that takes a value of 1 if the stock belongs to the bottom quintile based on its return over the months $t-3$ to $t-1$, and 0 otherwise. The dummy variable indicating decreases in the number of institutions over the previous quarter, $\mathrm{D}\left(\mathrm{NUM}_{i, t-3: t-1}^{-}\right)$, is based on the institution holdings information available in month $t-1$. We report results based on two classifications of institutions: the number of active institutions in firm $i$ as defined by Abarbanell et al. (2003) (ACTIVE) and the number of short-term institutions as measured by Gaspar et al. (2005) (SHORT_TERM).

In addition to $\mathrm{D}\left(3 \mathrm{MLOSER}_{i, t-3: t-1}\right)$ and $\mathrm{D}\left(\mathrm{NUM}_{i, t-3: t-1}^{-}\right)$, the regression specification allows for interaction of past returns with stock $i$ 's Amihud (2002) illiquidity measure $\left(\mathrm{ILLIQ}_{i, t}\right)$, stock turnover $\left(\mathrm{TURNOVER}_{i, t}\right)$, and return volatility $\left(\right.$ VOLATILITY $\left._{i, t}\right)$. The vector CONTROLS includes a supplementary set of predetermined firm-level control variables during the formation month $t$ that are known to predict monthly stock returns. These control variables are SIZE, the natural logarithm of market capitalization; BM, the book-to-market value of the firm's equity; and 6M_RETURN, the return on stock $i$ over the months $t-5$ and $t$ (all variables are defined in the Appendix). The coefficients of interest are $\beta_{3}$ and $\beta_{5}$, which capture the effect of past $3 \mathrm{M}$ returns and drop in the number of active institutions on return reversals. We report time-series averages (and the associated $t$-statistics) of the monthly cross-sectional regression coefficients in Table 8 .

We observe that decreases in the number of active institutions (ACTIVE) lead to significantly greater return reversals. The coefficient of lagged returns changes from -0.036 to -0.047 (model 1 ), and the change is significant $(t$ statistic $=-4.46)$. The effect of $3 \mathrm{M}$ losers on reversals is even stronger, with the corresponding coefficient increasing to -0.077 (model 1), and is highly significant. Hence, a drop in ACTIVE and in 3M losers predicts more reversals in returns, similar to our earlier findings. Consistent with the earlier literature, we find that stocks with higher Amihud measures reverse more. Although the other firmspecific variables, such as the Amihud illiquidity proxy, turnover, and volatility, also influence the degree of monthly reversals, our results on the effect of institutional exits are unaffected when we include these variables in the model. Our evidence is similar when we proxy active institutional investors by short-term institutions, SHORT_TERM (model 2). Moreover, we reach the same conclusion when the regressions are based on industry-adjusted reversals, as shown in models 3 and 4. Interestingly, the magnitudes of the effects of declines in active institutional investors and past 3M losers on industry-adjusted reversals are similar to those in models 1 and 2. 
TABLE 8

Return Reversals, Past Stock Returns, and Changes in Number of Institutions

Table 8 presents the results of the following monthly regressions in the style of Fama and MacBeth (1973) as well as $t$-statistics adjusted as per the method of Newey and West (1987):

$$
\begin{aligned}
r_{i, t+1}= & \beta_{0}+\beta_{1} r_{i, t}+\beta_{2} \mathrm{D}\left(3 \mathrm{MLOSER}_{i, t-3: t-1}\right)+\beta_{3} r_{i, t} \times \mathrm{D}\left(\text { 3MLOSER }_{i, t-3: t-1}\right) \\
& +\beta_{4} \mathrm{D}\left(\mathrm{NUM}_{i, t-3: t-1}^{-}\right)+\beta_{5} r_{i, t} \times \mathrm{D}\left(\mathrm{NUM}_{i, t-3: t-1}^{-}\right)+c^{\prime} \mathrm{CONTROLS}_{i, t}+\varepsilon_{i, t+1},
\end{aligned}
$$

where $r_{i, t+1}$ refers to the return on stock $i$ in month $t+1 ; \mathrm{D}\left(3 \mathrm{MLOSER} \mathrm{R}_{i, t-3: t-1}\right)$ is a dummy variable that takes a value of 1 if the accumulated stock return between month $t-3$ and $t-1$ is in the bottom quintile, and 0 otherwise; $\mathrm{D}\left(\mathrm{NUM}_{i, t-3 \cdot t-1}^{-}\right)$ is a dummy variable that takes a value of 1 if the number of active (ACTIVE) or short-term (SHORT_TERM) institutions decreases according to the most updated holding information of the institutions, and 0 otherwise; and the vector CONTROLS stacks all other control variables, including the natural logarithm of Amihud (2002) illiquidity (ILLIQ), stock turnover (TURNOVER), return volatility (VOLATILITY), the natural logarithm of firm's market capitalization (SIZE), the book-tomarket ratio of the firm's equity (BM), and returns on the stock over the past 6 months, from $t-5$ to $t$ (6M_RETURN). In models 1 and 2, $r_{i, t}$ (1M_RETURN) refers to the return on stock $i$ in month $t$, whereas in models 3 and 4 , it refers to

\begin{tabular}{|c|c|c|c|c|}
\hline & \multicolumn{2}{|c|}{ 1M_RETURN = Raw Return } & \multicolumn{2}{|c|}{ 1M_RETURN = Industry-Adjusted Return } \\
\hline & NUM $=$ ACTIVE & NUM $=$ SHORT_TERM & $\mathrm{NUM}=\mathrm{ACTIVE}$ & NUM $=$ SHORT_TERM \\
\hline & Model 1 & Model 2 & Model 3 & Model 4 \\
\hline Intercept & $\begin{array}{l}2.281^{\star \star \star} \\
(4.14)\end{array}$ & $\begin{array}{l}2.253^{\star \star \star} \\
(4.08)\end{array}$ & $\begin{array}{l}2.105^{\star \star *} \\
(3.91)\end{array}$ & $\begin{array}{l}2.073^{\star \star *} \\
(3.85)\end{array}$ \\
\hline 1M_RETURN & $\begin{array}{l}-0.036^{\star \star \star} \\
(-5.58)\end{array}$ & $\begin{array}{l}-0.037^{\star \star \star} \\
(-5.90)\end{array}$ & $\begin{array}{l}-0.060^{\star * *} \\
(-11.30)\end{array}$ & $\begin{array}{l}-0.061^{* \star *} \\
(-11.65)\end{array}$ \\
\hline $\mathrm{D}(3 \mathrm{MLOSER})$ & $\begin{array}{c}0.132 \\
(1.46)\end{array}$ & $\begin{array}{c}0.133 \\
(1.46)\end{array}$ & $\begin{array}{c}0.047 \\
(0.56)\end{array}$ & $\begin{array}{c}0.046 \\
(0.55)\end{array}$ \\
\hline $\mathrm{D}\left(\mathrm{NUM}^{-}\right)$ & $\begin{array}{l}-0.144^{\star \star \star} \\
(-3.86)\end{array}$ & $\begin{array}{l}-0.123^{\star \star \star} \\
(-3.88)\end{array}$ & $\begin{array}{l}-0.203^{\star \star *} \\
(-5.43)\end{array}$ & $\begin{array}{l}-0.171^{\star \star *} \\
(-5.10)\end{array}$ \\
\hline 1M_RETURN $\times$ D(3MLOSER $)$ & $\begin{array}{l}-0.041^{\star \star \star} \\
(-10.49)\end{array}$ & $\begin{array}{l}-0.042^{* \star *} \\
(-10.67)\end{array}$ & $\begin{array}{l}-0.040^{\star * *} \\
(-10.44)\end{array}$ & $\begin{array}{l}-0.041^{\star \star \star} \\
(-10.70)\end{array}$ \\
\hline 1M_RETURN $\times$ D(NUM $\left.{ }^{-}\right)$ & $\begin{array}{l}-0.011^{\star \star \star} \\
(-4.46)\end{array}$ & $\begin{array}{l}-0.004^{*} \\
(-1.78)\end{array}$ & $\begin{array}{l}-0.011^{* * *} \\
(-4.44)\end{array}$ & $\begin{array}{l}-0.005^{*} \\
(-1.92)\end{array}$ \\
\hline 1M_RETURN $\times$ ILLIQ & $\begin{array}{l}-0.002^{\star} \\
(-1.94)\end{array}$ & $\begin{array}{l}-0.002^{*} \\
(-1.90)\end{array}$ & $\begin{array}{l}-0.003^{* \star \star} \\
(-2.97)\end{array}$ & $\begin{array}{l}-0.003^{\star \star \star} \\
(-2.93)\end{array}$ \\
\hline 1M_RETURN $\times$ TURNOVER & $\begin{array}{l}0.001^{\star \star \star} \\
(5.45)\end{array}$ & $\begin{array}{l}0.001^{\star \star \star} \\
(5.49)\end{array}$ & $\begin{array}{l}0.002^{\star \star \star} \\
(6.60)\end{array}$ & $\begin{array}{l}0.002^{\star \star \star} \\
(6.62)\end{array}$ \\
\hline 1M_RETURN $\times$ VOLATILITY & $\begin{array}{l}0.004^{\star \star \star} \\
(3.19)\end{array}$ & $\begin{array}{l}0.004^{* * *} \\
(3.14)\end{array}$ & $\begin{array}{l}0.006^{* * *} \\
(6.02)\end{array}$ & $\begin{array}{l}0.006^{\star \star \star} \\
(5.88)\end{array}$ \\
\hline ILLIQ & $\begin{array}{l}-0.075^{\star} \\
(-1.92)\end{array}$ & $\begin{array}{l}-0.073^{*} \\
(-1.87)\end{array}$ & $\begin{array}{l}-0.066^{*} \\
(-1.69)\end{array}$ & $\begin{array}{l}-0.063 \\
(-1.61)\end{array}$ \\
\hline TURNOVER & $\begin{array}{c}0.008 \\
(1.38)\end{array}$ & $\begin{array}{c}0.008 \\
(1.38)\end{array}$ & $\begin{array}{l}0.012^{\star *} \\
(2.17)\end{array}$ & $\begin{array}{l}0.013^{\star *} \\
(2.18)\end{array}$ \\
\hline VOLATILITY & $\begin{array}{l}-0.339^{\star \star \star} \\
(-7.18)\end{array}$ & $\begin{array}{l}-0.339^{\star \star \star} \\
(-7.19)\end{array}$ & $\begin{array}{l}-0.324^{\star \star \star} \\
(-6.67)\end{array}$ & $\begin{array}{l}-0.324^{\star \star \star} \\
(-6.69)\end{array}$ \\
\hline SIZE & $\begin{array}{l}-0.130^{\star \star} \\
(-2.07)\end{array}$ & $\begin{array}{l}-0.127^{\star *} \\
(-2.02)\end{array}$ & $\begin{array}{l}-0.118^{*} \\
(-1.88)\end{array}$ & $\begin{array}{l}-0.114^{*} \\
(-1.84)\end{array}$ \\
\hline BM & $\begin{array}{l}0.387^{\star \star \star} \\
(3.74)\end{array}$ & $\begin{array}{l}0.387^{\star \star \star} \\
(3.74)\end{array}$ & $\begin{array}{l}0.395^{\star * *} \\
(3.82)\end{array}$ & $\begin{array}{l}0.395^{\star \star *} \\
(3.82)\end{array}$ \\
\hline 6M_RETURN & $\begin{array}{l}0.066^{\star \star \star} \\
(5.83)\end{array}$ & $\begin{array}{l}0.067^{\star \star \star} \\
(5.92)\end{array}$ & $\begin{array}{l}0.065^{\star \star \star} \\
(5.67)\end{array}$ & $\begin{array}{l}0.066^{\star \star \star} \\
(5.75)\end{array}$ \\
\hline Adj. $R^{2}$ & 0.067 & 0.067 & 0.066 & 0.066 \\
\hline
\end{tabular}
industry-adjusted return. ${ }^{*},{ }^{* *}$, and ${ }^{* * *}$ indicate significance at the $10 \%, 5 \%$, and $1 \%$ levels, respectively.

The results based on individual security returns in Table 8 corroborate the portfolio results in Tables 1 and 3, showing that declines in liquidity provision by active institutions increase contrarian profits, and vice versa. We also find that $3 \mathrm{M}$ returns and institutional exits jointly influence contrarian profits; neither effect subsumes the other. This is what we would expect if institutions exit for reasons other than past returns, and past returns at least partially capture the exit activity of noninstitutions in addition to institutions. Overall, the evidence accords with 
the notion that the decline in active investors and market-making capacity is a significant predictor of return reversals, even after controlling for other determinants of asset returns.

\section{Longer-Horizon Returns and Monthly Reversals}

Our hypothesis is that exits by active investors affect contrarian profits because of their impact on liquidity provision. However, such exits create an opportunity for other investors to enter and offset the decrease in liquidity provision. In the long run, such entry should restore liquidity capacity. Thus, whereas returns over the immediately preceding quarter strongly affect contrarian profits, returns measured in earlier months should have a more modest relation with such profits.

To examine this notion, in addition to using months $t-3$ to $t-1$ returns to define $3 \mathrm{M}$ winners and losers, our tests correlate the magnitude of reversals to stock returns from the earlier quarter (i.e., months $t-6$ to $t-4$ ), denoted as 4-6M. We expect 4-6M stock performance to be less important in predicting monthly reversals. To analyze the effect of 4-6M returns, stocks are independently sorted into quintiles according to past 4-6M and 3M returns at the end of each month $t$. For each of these 25 groupings, we examine the month $t+1$ reversal profits, where stocks are classified as winners and losers if they belong to top and bottom quintiles based on their returns in month $t$. The contrarian strategy evaluates the monthly return reversals as before, and the results are presented in Table 9.

The main finding for the full-sample period (Panel A of Table 9) is qualitatively similar to those in Table 1: $3 \mathrm{M}$ losers exhibit greater reversals than $3 \mathrm{M}$ winners, independent of the stock performance in the prior $t-6$ to $t-4$

\section{TABLE 9}

Returns to Contrarian Investment Strategies: Effect of Returns 2 Quarter Ago

In Table 9, at the end of each month $t$, stocks are independently sorted into quintiles according to their accumulated 3 -month returns in $t-4$ (i.e., $t-6$ to $t-4)$ and in $t-1(t-3$ to $t-1)$ and their 1 -month returns $(t)$. The loser (winner) portfolio comprises the bottom (top) quintile of stocks. Panel A reports, for each of the $25(5 \times 5)$ portfolios sorted by immediate past 3-month returns and the previous 3-month returns, the equal-weighted risk-adjusted return in month $t+1$ attributable to the strategy of going long (short) with the 1-month loser (winner) stocks. The profits are reported for the full sample (1980-2011) in Panel A as well as in 2 subperiods: 1980-1999 (Panel B) and 2000-2011 (Panel C). Risk-adjusted returns are based on a 4-factor model comprising the 3 Fama-French (1993) factors (market, size, and book-to-market) and the Pástor-Stambaugh liquidity factor. "LMW" reports the difference in profits between 3-month loser and winner portfolios, and $t$-statistics adjusted using the Newey-West (1987) method are reported in parentheses. *, **, and *** indicate significance at the $10 \%, 5 \%$, and $1 \%$ levels, respectively.

Panel A. 4-Factor Adjusted Returns to Contrarian Investment Strategies Sorted by Past Returns (1980-2011)

\begin{tabular}{|c|c|c|c|c|c|c|}
\hline \multirow{2}{*}{$\begin{array}{c}\text { Rank of Past } \\
\text { 3-Month Returns }\end{array}$} & \multicolumn{6}{|c|}{ Rank of Past 4- to 6-Month Returns } \\
\hline & Loser & 2 & 3 & 4 & Winner & LMW \\
\hline Loser & $\begin{array}{l}2.202^{\star \star \star *} \\
(7.23)\end{array}$ & $\begin{array}{l}1.644^{\star \star \star} \\
(5.89)\end{array}$ & $\begin{array}{l}1.510^{\star \star \star} \\
(5.17)\end{array}$ & $\begin{array}{l}1.222^{* \star *} \\
(4.30)\end{array}$ & $\begin{array}{l}0.714^{\star \star *} \\
(3.02)\end{array}$ & $\begin{array}{l}1.488^{\star \star \star \star} \\
(5.04)\end{array}$ \\
\hline 2 & $\begin{array}{l}1.032^{\star \star \star} \\
(3.34)\end{array}$ & $\begin{array}{l}0.669^{\star \star \star} \\
(2.72)\end{array}$ & 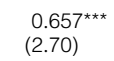 & $\begin{array}{c}0.032 \\
(0.15)\end{array}$ & $\begin{array}{l}-0.203 \\
(-0.71)\end{array}$ & $\begin{array}{l}1.235^{\star \star \star} \\
(3.68)\end{array}$ \\
\hline 3 & $\begin{array}{l}0.745^{\star \star \star} \\
(2.70)\end{array}$ & $\begin{array}{c}0.253 \\
(1.00)\end{array}$ & $\begin{array}{c}0.151 \\
(0.66)\end{array}$ & $\begin{array}{r}0.317 \\
(1.28)\end{array}$ & $\begin{array}{l}-0.016 \\
(-0.05)\end{array}$ & $\begin{array}{l}0.760^{\star \star} \\
(2.33)\end{array}$ \\
\hline 4 & $\begin{array}{c}0.029 \\
(0.13)\end{array}$ & $\begin{array}{l}-0.454^{\star} \\
(-1.76)\end{array}$ & $\begin{array}{c}0.124 \\
(0.50)\end{array}$ & $\begin{array}{l}-0.091 \\
(-0.36)\end{array}$ & $\begin{array}{l}-0.386 \\
(-1.40)\end{array}$ & $\begin{array}{c}0.415 \\
(1.39)\end{array}$ \\
\hline Winner & $\begin{array}{l}-0.312 \\
(-1.18)\end{array}$ & $\begin{array}{l}-0.247 \\
(-0.82)\end{array}$ & $\begin{array}{l}-0.273 \\
(-1.00)\end{array}$ & $\begin{array}{r}0.127 \\
(0.48)\end{array}$ & $\begin{array}{l}-0.203 \\
(-0.74)\end{array}$ & $\begin{array}{l}-0.110 \\
(-0.37)\end{array}$ \\
\hline LMW & $\begin{array}{l}2.515^{\star \star \star} \\
(7.52)\end{array}$ & $\begin{array}{l}1.892^{\star \star \star} \\
(5.34)\end{array}$ & 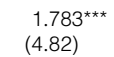 & $\begin{array}{l}1.095^{* * *} \\
(3.30)\end{array}$ & $\begin{array}{l}0.917^{\star \star \star *} \\
(3.01)\end{array}$ & \\
\hline
\end{tabular}


TABLE 9 (continued)

Returns to Contrarian Investment Strategies: Effect of Returns 2 Quarter Ago

Panel B. 4-Factor Adjusted Returns to Contrarian Investment Strategies Sorted by Past Returns (1980-1999)

\begin{tabular}{|c|c|c|c|c|c|c|}
\hline \multirow{2}{*}{$\begin{array}{c}\text { Rank of Past } \\
\text { 3-Month Returns } \\
\end{array}$} & \multicolumn{6}{|c|}{ Rank of Past 4- to 6-Month Returns } \\
\hline & Loser & 2 & 3 & 4 & Winner & LMW \\
\hline Loser & $\begin{array}{l}2.921^{\star \star \star} \\
(8.63)\end{array}$ & $\begin{array}{l}2.025^{\star \star \star} \\
(6.39)\end{array}$ & 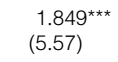 & $\begin{array}{l}1.464^{* \star *} \\
(4.54)\end{array}$ & $\begin{array}{l}0.787^{\star \star *} \\
(2.66)\end{array}$ & $\begin{array}{l}2.133^{\star \star \star} \\
(6.69)\end{array}$ \\
\hline 2 & $\begin{array}{l}1.241^{\star \star \star} \\
(4.07)\end{array}$ & $\begin{array}{l}0.804^{\star \star \star} \\
(2.75)\end{array}$ & $\begin{array}{l}0.894^{\star \star \star} \\
(2.86)\end{array}$ & $\begin{array}{l}0.103 \\
(0.39)\end{array}$ & $\begin{array}{l}-0.085 \\
(-0.29)\end{array}$ & $\begin{array}{l}1.327^{\text {} \star \star \star} \\
(4.06)\end{array}$ \\
\hline 3 & $\begin{array}{l}0.991^{\star \star \star} \\
(3.10)\end{array}$ & $\begin{array}{l}0.478 \\
(1.46)\end{array}$ & $\begin{array}{l}-0.178 \\
(-0.59)\end{array}$ & $\begin{array}{c}0.429 \\
(1.60)\end{array}$ & $\begin{array}{l}-0.249 \\
(-0.76)\end{array}$ & $\begin{array}{l}1.240^{\star \star \star} \\
(3.29)\end{array}$ \\
\hline 4 & $\begin{array}{l}0.195 \\
(0.82)\end{array}$ & $\begin{array}{l}-0.369 \\
(-1.46)\end{array}$ & $\begin{array}{l}0.245 \\
(0.94)\end{array}$ & $\begin{array}{l}-0.043 \\
(-0.15)\end{array}$ & $\begin{array}{l}-0.289 \\
(-0.97)\end{array}$ & $\begin{array}{c}0.484 \\
(1.48)\end{array}$ \\
\hline Winner & $\begin{array}{l}-0.369 \\
(-1.16)\end{array}$ & $\begin{array}{l}-0.455 \\
(-1.58)\end{array}$ & $\begin{array}{l}-0.405 \\
(-1.37)\end{array}$ & $\begin{array}{c}0.014 \\
(0.05)\end{array}$ & $\begin{array}{l}-0.381 \\
(-1.33)\end{array}$ & $\begin{array}{c}0.012 \\
(0.04)\end{array}$ \\
\hline LMW & $\begin{array}{l}3.289^{\star \star \star} \\
(8.06)\end{array}$ & $\begin{array}{l}2.480^{\star \star \star} \\
(7.33)\end{array}$ & $\begin{array}{l}2.254^{\star \star \star} \\
(5.99)\end{array}$ & $\begin{array}{l}1.450^{\star * *} \\
(3.60)\end{array}$ & $\begin{array}{l}1.168^{\star \star *} \\
(3.48)\end{array}$ & \\
\hline
\end{tabular}

Panel C. 4-Factor Adjusted Returns to Contrarian Investment Strategies Sorted by Past Returns (2000-2011)

\begin{tabular}{|c|c|c|c|c|c|c|}
\hline \multirow{2}{*}{$\begin{array}{c}\text { Rank of Past } \\
\text { 3-Month Returns }\end{array}$} & \multicolumn{6}{|c|}{ Rank of Past 4- to 6-Month Returns } \\
\hline & Loser & 2 & 3 & 4 & Winner & LMW \\
\hline Loser & $\begin{array}{l}1.544^{\star \star \star} \\
(2.80)\end{array}$ & $\begin{array}{l}1.380^{* \star} \\
(2.31)\end{array}$ & $\begin{array}{l}1.373^{\star \star} \\
(2.47)\end{array}$ & $\begin{array}{l}1.269^{* *} \\
(2.48)\end{array}$ & $\begin{array}{l}0.920^{\star *} \\
(2.08)\end{array}$ & $\begin{array}{r}0.625 \\
(1.08)\end{array}$ \\
\hline 2 & $\begin{array}{c}0.845 \\
(1.39)\end{array}$ & $\begin{array}{c}0.570 \\
(1.36)\end{array}$ & $\begin{array}{c}0.545 \\
(1.39)\end{array}$ & $\begin{array}{c}0.139 \\
(0.41)\end{array}$ & $\begin{array}{c}0.040 \\
(0.08)\end{array}$ & $\begin{array}{r}0.806 \\
(1.32)\end{array}$ \\
\hline 3 & $\begin{array}{c}0.695 \\
(1.32)\end{array}$ & $\begin{array}{r}0.177 \\
(0.45)\end{array}$ & $\begin{array}{l}0.777^{\star \star \star} \\
(2.07)\end{array}$ & $\begin{array}{c}0.309 \\
(0.65)\end{array}$ & $\begin{array}{l}0.720 \\
(1.57)\end{array}$ & $\begin{array}{l}-0.025 \\
(-0.04)\end{array}$ \\
\hline 4 & $\begin{array}{l}-0.045 \\
(-0.11)\end{array}$ & $\begin{array}{l}-0.231 \\
(-0.55)\end{array}$ & $\begin{array}{c}0.343 \\
(0.81)\end{array}$ & $\begin{array}{c}0.168 \\
(0.39)\end{array}$ & $\begin{array}{l}-0.319 \\
(-0.70)\end{array}$ & $\begin{array}{r}0.275 \\
(0.52)\end{array}$ \\
\hline Winner & $\begin{array}{c}0.135 \\
(0.34)\end{array}$ & $\begin{array}{l}0.143 \\
(0.23)\end{array}$ & $\begin{array}{c}0.320 \\
(0.70)\end{array}$ & $\begin{array}{c}0.640 \\
(1.20)\end{array}$ & $\begin{array}{c}0.263 \\
(0.47)\end{array}$ & $\begin{array}{l}-0.128 \\
(-0.22)\end{array}$ \\
\hline LMW & $\begin{array}{l}1.409^{\star \star} \\
(2.37)\end{array}$ & $\begin{array}{r}1.237 \\
(1.60)\end{array}$ & $\begin{array}{c}1.052 \\
(1.54)\end{array}$ & $\begin{array}{c}0.629 \\
(1.15)\end{array}$ & $\begin{array}{c}0.657 \\
(1.00)\end{array}$ & \\
\hline
\end{tabular}

months. The reversal profits are also higher if the stocks declined 2 quarters ago, indicating that $4-6 \mathrm{M}$ returns incrementally predict reversals in month $t+1$. However, the more recent quarter has a much stronger effect on the magnitude of the reversals.

The subperiod results in Panels B and C of Table 9 reveal that 3M losers continue to earn contrarian profits in both subperiods; however, although the impact of 4-6M returns on reversals is significant in the first subperiod, it is not reliably positive in the later subperiod. Among the $3 \mathrm{M}$ losers, we find that $4-6 \mathrm{M}$ losers predict significantly higher reversal profits than 4-6M winners in the 1980-1999 period, consistent with high participation costs delaying the entry of additional liquidity providers. On the other hand, the insignificant influence of $4-6 \mathrm{M}$ returns on reversals in the recent decade is consistent with the view that the entry of new liquidity providers has become less costly. In unreported results, we consider the effect of returns in months $t-9$ to $t-7$ and months $t-12$ to $t-10$ and find them to be irrelevant in predicting reversals. These results indicate that even in the earlier subperiod, past returns have only a temporary effect on the magnitude of return reversals. 


\section{Conclusion}

We shed light on cross-sectional variation in monthly contrarian profits in equity markets. Specifically, we find that stocks that perform poorly in the previous 3 months from $t-3$ to $t-1$ exhibit the greatest return reversals over months $t$ and $t+1$. We show that our finding is related to changes in the number of active investors in the stock, which, in turn, influence liquidity provision. We find that large declines in stock prices over the past quarter are associated with declines in institutional investor participation during that period and with material increases in reversals-based profits in the 2 months following the quarter. Moreover, we find that drops in the number of active institutions over the past quarter are associated with increased monthly reversals. We also find that the proportion of volume contributed by LS institutions (as defined by Anand et al. (2013)) decreases (relative to that 1 quarter ago) for past-quarter losers. We find that hedge fund holdings (that proxy for active LS agents, as noted by Franzoni and Plazzi (2013)) also reduce for past losers.

We also find that losers in the monthly contrarian strategy do not experience higher abnormal turnover than winners and that contrarian profits do not arise primarily from long positions in losers. This implies that our results cannot be fully explained by price pressure resulting from prolonged institutional sales ("fire sales") in losers. Further, variations in return volatility depending on prior stock performance also do not fully account for our results. Although alternative explanations may account for part of our results, overall, the picture is consistent with the notion that fluctuations in the number of active institutions are an important determinant of dynamic variations in the rewards to liquidity provision (i.e., reversal profits).

Our analysis suggests several avenues for future research. First, whether events such as analyst downgrades and adverse news announcements lead to investor exits and increased reversals deserves a rigorous investigation. It may also be of interest to ascertain whether our results apply in derivatives markets, which undergo sharp price drops and consequent investor exits. Finally, how our results vary across countries with different degrees of institutional participation also merits investigation. These and other related issues are left for future research.

\section{Appendix. Variable Definitions}

TRADING_STYLE The trading style of institution $f$ in a given month $t$, computed as

$$
\text { TRADING_STYLE }_{f, t}=\frac{\sum_{i \in Q} \operatorname{VOLUME}_{i, f, t, \mathrm{WITH}}-\sum_{i \in Q} \operatorname{VOLUME}_{i, f, t, \mathrm{AGAINST}}}{\sum_{i \in Q} \operatorname{VOLUME}_{i, f, t, \mathrm{WITH}}+\sum_{\mathrm{i} \in \mathrm{Q}} \operatorname{VOLUME}_{i, f, t, \mathrm{AGAINST}}},
$$

where $\operatorname{VOLUME}_{i, f, t, \mathrm{WITH}}$ refers to the dollar volume of stock $i$ by institution $f$ in month $t$, traded with the daily stock return; more specifically, it is a buy order if the stock return for the day is positive or a sell order if the stock return for the day is negative. VOLUME $E_{i, f, t, \text { AGAINST }}$ refers to the dollar volume of stock $i$ traded against the stock return by institution $f$ in month $t$, and it is defined as a buy order if the stock return for the day is negative or a sell order if the stock return for the day is positive. $Q$ represents the set of companies traded by institution $f$. Institutions are assigned into tercile portfolios based on trading style in each month, and the bottom (top) tercile 
institutions are classified as LS (LD) institutions. See Anand et al. (2013) for more details.

ACTIVE The number of active institutions in each quarter. Institutions are classified into five types (obtained from Brian Bushee's Web site: http://acct.wharton.upenn .edu/faculty/bushee/IIclass.html): bank trust, insurance company, investment company, independent investment advisor, and others (corporate/private pension fund, public pension fund, university and foundation endowments, miscellaneous). The investment company and independent investment advisor categories are termed "active investors."

SHORT_TERM The number of active, short-term institutions in each quarter. More specifically, the churn rate of institution $f$ in a given quarter $q$ is computed as

$$
\mathrm{CR}_{f, q}=\frac{\sum_{i \in Q}\left|N_{i, f, q} P_{i, q}-N_{i, f, q-1} P_{i, q-1}-N_{i, f, q-1} \Delta P_{i, q}\right|}{\sum_{i \in Q} \frac{N_{i, f, q} P_{i, q}+N_{i, f, q-1} P_{i, q-1}}{2}},
$$

where $N_{i, f, q}$ refers to the number of shares of stock $i$ held by institution $f$ in quarter $q, P_{i, q}$ refers to the stock price at the same time, and $Q$ represents the set of companies held by institution $f$. The average churn rate is later computed over the past 4 quarters to rank the institutions, and those with an above-median average churn rate are classified as short-term institutions in each quarter. See Gaspar et al. (2005) for more details.

VOLATILITY The return volatility is the standard deviation of the daily stock return in each month.

IDIOVOL For each stock $i$, a Fama and French (1993) 3-factor model is estimated using daily returns in each month $t$ as follows:

$$
R_{i, d, t}^{e}=\alpha_{i}+\beta_{\mathrm{MKT}, i} \mathrm{MKT}_{d, t}+\beta_{\mathrm{SMB}, i} \mathrm{SMB}_{d, t}+\beta_{\mathrm{HML}, i} \mathrm{HML}_{d, t}+e_{i, d, t},
$$

where $R_{i, d, t}^{e}$ refers to the excess return of stock $i$ on day $d$ of month $t$, and $\mathrm{MKT}_{d, t}$, $\mathrm{SMB}_{d, t}$, and $\mathrm{HML}_{d, t}$ refer to the 3 Fama-French factors (market, size, and book-tomarket). The idiosyncratic volatility (IDIOVOL) for stock $i$ in month $t$ is computed as the standard deviation of the residual $e_{i, d, t}$, following Ang, Hodrick, Xing, and Zhang (2006).

ILLIQ The Amihud illiquidity measure in a given month $t$, computed as

$$
\mathrm{ILLIQ}_{i, t}=\frac{1}{D_{i, t}} \sum_{d=1}^{D_{i, t}} \frac{\left|R_{i, t, d}\right|}{\mathrm{DVOL}_{i, t, d}} \times 10^{6},
$$

where $R_{i, t, d}$ is the return for stock $i$ on day $d$ of month $t, \mathrm{DVOL}_{i, t, d}$ is the dollar trading volume of stock $i$ on day $d$ of month $t$, and $D_{i, t}$ represents the number of trading days for stock $i$ in month $t$. In addition, NASDAQ trading volume is adjusted following Gao and Ritter (2010). We employ the logarithm of monthly stock illiquidity in empirical tests. ${ }^{18}$

TURNOVER The stock turnover in a given month $t$, computed as

$$
\operatorname{TURNOVER}_{i, t}=\frac{1}{D_{i, t}} \sum_{d=1}^{D_{i, t}} \frac{\operatorname{VOL}_{i, t, d}}{\operatorname{SHROUT}_{i, t, d}} \times 10^{2},
$$

\footnotetext{
${ }^{18}$ Specifically, prior to Feb. 1, 2001, we divide NASDAQ volume by 2. From Feb. 1, 2001 to Dec. 31, 2001, we divide NASDAQ volume by 1.8. For the years 2002 and 2003, we divide NASDAQ volume by 1.6. No adjustment is made from 2004 onward.
} 
where $\operatorname{VOL}_{i, t, d}$ refers to the trading volume of stock $i$ on day $d$ of month $t$, and SHROUT $_{i, t, d}$ refers to the shares outstanding at the same time. In addition, NASDAQ trading volume is adjusted following Gao and Ritter (2010) as in ILLIQ.

SIZE The logarithm of the market capitalization of a stock, computed as the month-end stock price multiplied by shares outstanding, in millions.

BM The book-to-market ratio in a given quarter $q$, computed as

$$
\mathrm{BM}_{i, q}=\frac{\mathrm{BE}_{i, q}}{\mathrm{ME}_{i, q}},
$$

where $\mathrm{BE}_{i, q}$ refers to the book value of equity of stock $i$ in quarter $q$, computed as the summation of stockholders' equity and deferred taxes, minus the preferred stock; and $\mathrm{ME}_{i, q}$ refers to its market value at the end of the same quarter.

6M_RETURN The average monthly stock return over the past 6 months.

\section{References}

Abarbanell, J.; B. Bushee; and J. Raedy. "Institutional Investor Preferences and Price Pressure: The Case of Corporate Spin-Offs.” Journal of Business, 76 (2003), 233-261.

Agarwal, V.; V. Fos; and W. Jiang. "Inferring Reporting-Related Biases in Hedge Fund Databases from Hedge Fund Equity Holdings.” Management Science, 59 (2013), 1271-1289.

Agarwal, V.; W. Jiang; Y. Tang; and B. Yang. "Uncovering Hedge Fund Skill from the Portfolio Holdings They Hide.” Journal of Finance, 68 (2013), 739-783.

Amihud, Y. "Illiquidity and Stock Returns: Cross-Section and Time-Series Effects." Journal of Financial Markets, 5 (2002), 31-56.

Anand, A.; P. Irvine; A. Puckett; and K. Venkataraman. "Performance of Institutional Trading Desks: An Analysis of Persistence in Trading Costs." Review of Financial Studies, 25 (2012), 557-598.

Anand, A.; P. Irvine; A. Puckett; and K. Venkataraman. "Institutional Trading and Stock Resiliency: Evidence from the 2007-2009 Financial Crisis.” Journal of Financial Economics, 108 (2013), 773-797.

Ang, A.; R. Hodrick; Y. Xing; and X. Zhang. "The Cross-Section of Volatility and Expected Returns." Journal of Finance, 61 (2006), 259-299.

Aragon, G. "Share Restrictions and Asset Pricing: Evidence from the Hedge Fund Industry." Journal of Financial Economics, 83 (2007), 33-58.

Aragon, G., and P. Strahan. "Hedge Funds as Liquidity Providers: Evidence from the Lehman Bankruptcy.” Journal of Financial Economics, 103 (2012), 570-587.

Asness, C.; J. Liew; and R. Stevens. "Parallels between the Cross-Sectional Predictability of Stock and Country Returns.” Journal of Portfolio Management, 23 (1997), 79-87.

Asparouhova, E.; H. Bessembinder; and I. Kalcheva. "Noisy Prices and Inference Regarding Returns." Journal of Finance, 68 (2013), 665-714.

Avramov, D.; T. Chordia; and A. Goyal. "Liquidity and Autocorrelations in Individual Stock Returns." Journal of Finance, 61 (2006), 2365-2394.

Barberis, N.; A. Shleifer; and R. Vishny. "A Model of Investor Sentiment." Journal of Financial Economics, 49 (1998), 307-343.

Benston, G., and R. Hagerman. "Determinants of Bid-Ask Spreads in the Over-the-Counter Market." Journal of Financial Economics, 1 (1974), 353-364.

Brunnermeier, M., and L. Pedersen. "Market Liquidity and Funding Liquidity." Review of Financial Studies, 22 (2009), 2201-2238.

Chemmanur, T.; S. He; and G. Hu. "The Role of Institutional Investors in Seasoned Equity Offerings." Journal of Financial Economics, 94 (2009), 384-411.

Chordia, T.; R. Roll; and A. Subrahmanyam. "Recent Trends in Trading Activity and Market Quality." Journal of Financial Economics, 101 (2011), 243-263.

Chordia, T.; A. Subrahmanyam; and Q. Tong. "Have Capital Market Anomalies Attenuated in the Recent Era of High Liquidity and Trading Activity?" Journal of Accounting and Economics, 58 (2014), 51-58.

Conrad, J.; G. Kaul; and M. Nimalendran. "Components of Short-Horizon Individual Security Returns." Journal of Financial Economics, 29 (1991), 365-384.

Coval, J., and E. Stafford. "Asset Fire Sales (and Purchases) in Equity Markets.” Journal of Financial Economics, 86 (2007), 479-512. 
Da, Z., and P. Gao. "Clientele Change, Liquidity Shock, and the Return on Financially Distressed Stocks.” Journal of Financial and Quantitative Analysis, 45 (2010), 27-48.

Da, Z.; Q. Liu; and E. Schaumburg. “A Closer Look at the Short-Term Return Reversal.” Management Science, 60 (2014), 658-674.

Daniel, K.; D. Hirshleifer; and A. Subrahmanyam. "Investor Psychology and Security Market Underand Overreactions." Journal of Finance, 53 (1998), 1839-1885.

Datar, V.; N. Naik; and R. Radcliffe. "Liquidity and Asset Returns: An Alternative Test." Journal of Financial Markets, 1 (1998), 203-219.

Fama, E., and K. French. "Common Risk Factors in the Returns on Stocks and Bonds." Journal of Financial Economics, 33 (1993), 3-56.

Fama, E., and K. French. "Industry Costs of Equity." Journal of Financial Economics, 43 (1997), 153-193.

Fama, E., and K. French. "Dissecting Anomalies.” Journal of Finance, 63 (2008), 1653-1678.

Fama, E., and J. MacBeth. "Risk, Return, and Equilibrium: Empirical Tests." Journal of Political Economy, 71 (1973), 607-636.

Franzoni, F., and A. Plazzi. "What Constrains Liquidity Provision? Evidence from Hedge Fund Trades." Working Paper, University of Lugano (2013).

Froot, K.; D. Scharfstein; and J. Stein. "Herd on the Street: Informational Inefficiencies in a Market with Short-Term Speculation.” Journal of Finance, 47 (1992), 1461-1484.

Gao, X., and J. Ritter. "The Marketing of Seasoned Equity Offerings." Journal of Financial Economics, 97 (2010), 33-52.

Gaspar, J.; M. Massa; and P. Matos. "Shareholder Investment Horizons and the Market for Corporate Control.” Journal of Financial Economics, 76 (2005), 135-165.

George, T., and C.-Y. Hwang. "The 52-Week High and Momentum Investing." Journal of Finance, 59 (2004), 2145-2176.

Glosten, L.; R. Jagannathan; and D. Runkle. "On the Relation between the Expected Value and the Volatility of the Nominal Excess Return on Stocks." Journal of Finance, 48 (1993), 1779-1801.

Goldstein, M.; P. Irvine; E. Kandel; and Z. Weiner. "Brokerage Commissions and Institutional Trading Patterns.” Review of Financial Studies, 22 (2009), 5175-5212.

Goldstein, M.; P. Irvine; and A. Puckett. "Purchasing IPOs with Commissions." Journal of Financial and Quantitative Analysis, 46 (2011), 1193-1225.

Gromb, D., and D. Vayanos. "Equilibrium and Welfare in Markets with Financially Constrained Arbitrageurs.” Journal of Financial Economics, 66 (2002), 361-407.

Grossman, S., and M. Miller. "Liquidity and Market Structure." Journal of Finance, 43 (1988), $617-633$.

Hameed, A.; W. Kang; and S. Viswanathan. "Stock Market Declines and Liquidity." Journal of Finance, 65 (2010), 257-293.

Hameed, A., and M. Mian. "Industries and Stock Return Reversals." Journal of Financial and Quantitative Analysis, 50 (2015), 89-117.

Hirshleifer, D.; A. Subrahmanyam; and S. Titman. "Security Analysis and Trading Patterns When Some Investors Receive Information before Others.” Journal of Finance, 49 (1994), 1665-1698.

Ho, T., and H. Stoll. "The Dynamics of Dealer Markets under Competition." Journal of Finance, 38 (1983), 1053-1074.

Huang, J., and J. Wang. "Liquidity and Market Crashes." Review of Financial Studies, 22 (2009), 2607-2643.

Huang, W.; Q. Liu; G. Rhee; and L. Zhang. "Return Reversals, Idiosyncratic Risk, and Expected Returns." Review of Financial Studies, 23 (2010), 147-168.

Jegadeesh, N. "Evidence of Predictable Behavior in Security Returns." Journal of Finance, 45 (1990), 881-898.

Jegadeesh, N., and S. Titman. "Returns to Buying Winners and Selling Losers: Implications for Stock Market Efficiency." Journal of Finance, 48 (1993), 65-92.

Jegadeesh, N., and S. Titman. "Short-Horizon Return Reversals and the Bid-Ask Spread." Journal of Financial Intermediation, 4 (1995), 116-132.

Jylhä, P.; K. Rinne; and M. Suominen. "Do Hedge Funds Supply or Demand Immediacy?" Review of Finance, 18 (2014), 1259-1298.

Kaniel, R.; G. Saar; and S. Titman. "Individual Investor Trading and Stock Returns." Journal of Finance, 63 (2008), 273-310.

Ke, B., and K. Petroni. "How Informed Are Actively Trading Institutional Investors? Evidence from Their Trading Behavior before a Break in a String of Consecutive Earnings Increases." Journal of Accounting Research, 42 (2004), 895-927.

Lou, D. "A Flow-Based Explanation for Return Predictability." Review of Financial Studies, 25 (2012), 3457-3489. 
Nagel, S. "Evaporating Liquidity.” Review of Financial Studies, 25 (2012), 2005-2039.

Newey, W., and K. West. "A Simple Positive-Definite Heteroskedasticity and Autocorrelation Consistent Covariance Matrix.” Econometrica, 55 (1987), 703-708.

O'Hara, M., and G. Oldfield. "The Microeconomics of Market Making." Journal of Financial and Quantitative Analysis, 21 (1986), 361-376.

Pástor, L., and R. Stambaugh. "Liquidity Risk and Expected Stock Returns.” Journal of Political Economy, 113 (2003), 642-685.

Puckett, A., and X. Yan. "The Interim Trading Skills of Institutional Investors.” Journal of Finance, 66 (2011), 601-633.

Ritter, J., and N. Chopra. "Portfolio Rebalancing and the Turn-of-the-Year Effect." Journal of Finance, 44 (1989), 149-166.

Sadka, R. "Liquidity Risk and the Cross-Section of Hedge-Fund Returns." Journal of Financial Economics, 98 (2010), 54-71.

Spiegel, M., and A. Subrahmanyam. "On Intraday Risk Premia.” Journal of Finance, 50 (1995), 319-339.

Stoll, H. "The Supply of Dealer Services in Securities Markets.” Journal of Finance, 33 (1978), 1133-1151.

Yan, X., and Z. Zhang. "Institutional Investors and Equity Returns: Are Short-Term Institutions Better Informed?" Review of Financial Studies, 22 (2009), 893-924. 